\title{
FIGURING THE MALE AND FEMALE: FIRE AND WATER IN BRADBURY'S (SCIENCE) FICTION
}

\author{
Yuliya Davydyuk*, Nataliya Panasenko ${ }^{1}$ \\ Corresponding author*
}

Davydyuk, Yu., Panasenko, N. Figuring the male and female: fire and water in Bradbury's (science) fiction // Lege artis. Language yesterday, today, tomorrow. The Journal of University of SS Cyril and Methodius in Trnava. Warsaw: De Gruyter Open, 2016, vol. 1 (1), June 2016. p. 4-74. DOI: 10.1515/lart-2016-0001 ISSN 2453-8035

\begin{abstract}
The article highlights the results of the investigation of the literary FIRE and WATER concepts and their basic characteristics from a cognitive point of view. The research of the literary FIRE and WATER concepts was carried out in three steps - revealing their notional, image- and sense-bearing components. The results show that the FIRE concept is mostly personified into the image of A MAN, while the WATER concept is mostly personified into the image of A WOMAN.
\end{abstract}

Keywords: the male, the female, literary concepts, Ray Bradbury, symbol, the FIRE concept, the WATER concept, concept-element, conceptual metaphor, embodiment, image, text type.

Sun... is our cup of energy, fire, vibration... Here, from this cup, all good men of science and religion: Drink! Warm yourselves against the night of ignorance, the long snows of superstition, the cold winds of disbelief, and from the great fear of darkness in each man. (Ray Bradbury "The golden apples of the sun")

\section{Introduction}

Concepts are mental entities: each concept contains knowledge of the world important to a human; the system of concepts forms the worldview image, which shows the vision

\footnotetext{
${ }^{1}$ The article we present here is a pilot research done especially for "Lege artis" journal. It is not connected with our PhD or postdoctoral papers. Thus various and to some extend unusual approaches to Ray Bradbury's text analysis is all our responsibility. We are open for further discussion and will be much obliged for critical remarks if any. We would like to express our sincere gratitude to all the reviewers and language consultants who kindly agreed to review our paper presented in this volume. We want to acknowledge that some pieces of advice were very efficient and helped us a lot during the process of creating this completely new project. We are pleased to share this paper with all the readers and hope that they will appreciate our work. 
and perceptions of reality by humans, their special conceptual "picture" (Маслова 2008: 45). Based on many statements, interpretations, types of the concept and their modelling, it is considered a multidimensional notion, which can have rational, emotional, abstract, specific, universal, ethnic, national, and personal aspects. Our research specifically focuses on literary concepts, which are considered to be units of individual consciousness, author's conceptual domain (Тарасова 2012) and units of poetic image of the world (Болотова 2007).

The aim of our research is to show how literary concepts - FIRE and WATER - are embodied in the works by Bradbury, paying attention to three components or layers of the concept: notional, image- and sense-bearing. Each component is described separately; using the componential and definitional analyses of lexemes of these concepts we present the principal meanings the FIRE and WATER concepts convey. The main images realised in these concepts are represented via building various conceptual schemes, based on personification and conceptual metaphors, which are mostly connected with the male or female embodiment.

In our research, we take into account the symbolic nature of FIRE and WATER as these concepts are well-known global symbols that exist in many cultures. Moreover, symbols are explications of concepts, having a symbolic layer in their structures (Тарасова 2012: 49). Besides this, they are known as one of four basic elements, among which earth and air are also found. Using the information presented in modern dictionaries about the literary FIRE and WATER concepts, which can be regarded as global symbols, we will systematize the positive and negative meanings they contain and connect them with the images, arisen due to investigation of three basic components of the FIRE and WATER concepts, especially the image-bearing component.

We also trace how the male principle (Yang) and the female principle (Yin) that are key principles of Chinese philosophy are reflected in Bradbury's fiction, as the FIRE and WATER are known to be Yang and Yin elements in Chinese philosophy 
correspondingly. It is worth mentioning that Bradbury professed no particular religion: being a representative of classical American culture, he was not a Christian in the strict sense of this word; perhaps he was an ecumenist in the broad sense (Panasenko 2013). In a recent interview, Bradbury told Times: "My religion encompasses all religions" (Ford 2012), yet we find it reasonable to touch upon Chinese theme and provide certain parallel with this philosophy, especially in the light of investigating of such concepts, as FIRE and WATER. Hence, we will try to prove our plausible assumption that Bradbury implicitly uses Chinese philosophy of life (Yin and Yang) in his works as a base for personification.

The final part of our research presents the psycholinguistic analysis of Bradbury's works which gives us possibility to find out to what types of texts - light, active, dark, sad, merry, beautiful and complex (Белянин 2000: 75) - our case study belongs to. This analysis also demonstrates how the FIRE and WATER concepts are revealed in Bradbury's works according to this classification.

\section{Concept as a basic unit of knowledge}

As far as it is next to impossible to highlight in our article all existing schools and studies dealing with concept, here we will focus mainly on most popular definitions of the concept, its characteristics, structure, typology, functional properties and some other aspects important for us. Concept as component of our consciousness and knowledge of the world is the subject of study of many sciences: philosophy, psychology, cultural linguistics, conceptology, and cognitive linguistics in particular. Despite the fact that the term "concept" is used by the scholars, working in various linguistic areas, there is no single definition of this term. This does not indicate the lack of common views on the concept nature and its functions, but it does indicate the wealth of its characteristics and properties (Приходько 2008: 47).

As an operative unit of memory, conceptual worldview, reflected in the human's psyche (Кубрякова 1996), as an informational cognitive structure of the consciousness, 
organized in a specific way and built in the collective or individual conceptual domain (Селіванова 2008: 417), as a quantum of experienced knowledge (Карасик 2004), reflecting the human experience, concept is a unit of "collective unconscious", partially verbalized by language means, which includes a significant proportion of nonverbal information (Воркачёв 2004; Степанов 1997). A deep analysis of concepts has many approaches integrated in the following trends and schools: 1) cultural (Stepanov); 2) linguo-cultural (Karasik, Slyshkin, Vorkachyov); 3) logical-eidetic (Wierzbicka, Zhabotynskaya); 4) semantic-cognitive (Arutiunova, Boldyrev, Sternin); 5) cognitivepoetic (Belekhova, Kaganovska, Nikonova, Vorobyova); 6) cognitive-discursive (Koubriakova, Shevchenko), and 7) philosophically semiotic (Kravchenko). All these trends recognize the concept as a basic unit of knowledge; the differences relate to the focus on a particular type of concepts and different interpretation of the relationship between the concept as part of cultural worldview and lexical meaning (Шевченко 2006).

Based on generalization of existing experience, scholars formulated the concept characteristics, such as value, complexity of existence, restriction of consciousness, conventionality and ambiguity, variability, difficult structure, three-level language implementation (Приходько 2008; Цьмух 2011) and its other properties (Bishop 2007; Bucharov 2013; Fauconnier \& Turner 1998; 2002; Fodor 1998; Jackendoff 1992; 1999; Morton 2006; Murphy 2002).

Concept has a very complex structure and this structure is defined by lots of scholars in a different way. Nowadays it is scientifically proven that concept is a plurality (Огнева 2013: 30). Below we present concept structures mainly proposed by Popova and Sternin (2010: 104-105), which we have enlarged by studies that are important for our research:

I. Stepanov (1997) assumes that the structure of concept includes basic (actual) component, additional (passive, historical) component and internal form, or 
etymology, which is mainly defined only by researchers. Each of these layers is different in formation and semantics.

II. Vorkachev (2004) singles out in concept notional component (identification and definitional structure); image component (cognitive metaphors that form the concept in consciousness) and significant component - etymological, associative concept characteristics that define its place in the lexical and grammatical system of the language.

III. Karasik (2004) distinguishes in concept structure image-perceptive component, notional (factual information) and evaluative component (estimation and behavioural norms). This classification (notional, image and evaluative component) is supported by Ogneva (2013: 33-34) and Prikhodko (2008).

IV. Slyshkin describes four zones in concept structure - basic (intrazone, extrazone) and two additional - quasizone and quasiextrazone (Слышкин 2004: 17-18). Intrazone includes concept features that reflect the signs of denotation; extrazone includes features that are the part of figurative meanings; quasizone and quasiextrazone are related to formal associations.

V. Popova and Sternin refer to the basic structure of concept image, information content and interpretive field. The presence of image component in concept is determined by the neurolinguistic nature of universal subject code: sensory image codes concept, forming a unit of universal subject code. Sensory image of the concept structure is heterogeneous; it is created by cognitive perceptual features formed in the native speakers' minds as a result of demonstrating their surrounding reality through the senses (perceptual image) and by image features, formed by metaphorical understanding of the relevant object or phenomenon (metaphorical or cognitive image). Information content of the concept includes minimum of cognitive features that define basic, the most important features of conceptualized object or phenomenon. Interpretive field of concept includes cognitive signs, which in any aspect interpret basic information content of the concept and emerge from it (Попова, Стернин 2007). VI. Although Maslova (2008: 6) supports the idea of the concept structure proposed by Stepanov, she points out that in a broader sense concept structure can be seen as a field, 
in the centre of which there is the basic notion (core concept) and on the periphery all that have been introduced by culture, traditions, people and personal experiences. VII. Rudakova (2002: 52) singles out single-layer, multi-layer and segmental concepts.

As we can see, most scholars distinguish image as part of the concept, certain information, conceptual core and some extra features (e.g., evaluative, etymological and others) which demonstrate the basic similarity in understanding of the concept structure in different scientific schools.

Concepts also have their own modelling, which is noteworthy to mention because it has many interpretations. Concept macrostructure is known to have core and periphery, but there are other modelling methods, singled out by the researchers, such as: 1) determination of means of "entrance to the concept" from the text;2) metalinguistic titles of the concept (Приходько 2008); 3) componential and etymological analysis; 4) conceptual analysis using reference and encyclopaedic sources; 5) building of synonymous or semiotic lines; 6) reconstruction of image layer of the concept using conceptual tropes; 7) determining the evaluative component of the concept; 8) establishing associative links between concepts: building a network of concepts (Ніконова 2008; Ніконова 2008a); 9) conceptual construction in the form of matrix and network (Жаботинская 2009); 10) mental-psyche complex (Селиванова 2000: 113-114), which includes a verbalized thinking component (knowledge in the language and knowledge about the language); non-verbalized thinking component (experiential knowledge, knowledge of culture); verbal and non-verbal images of gestalt; mental functions that correlate with thinking; archetypes. This model can be viewed as integrative and organized entity that correlates with conceptual system, consciousness and collective unconscious. In general, while modelling the concept, the researchers combine two models - a frame model and field model (Ніконова 2008: 181).

Concept as an "umbrella" term (Воркачёв 2003; Кубрякова et al. 1996), covering the subject areas of several scientific fields, has its typology. According to Popova and 
Sternin (2010: 116), typology of concept is possible and necessary, because there are different types of knowledge represented by concepts. Concepts are divided into several sorts by the type of knowledge and content, and the degree of abstraction:

1) specific sensory image (the image of a particular object or phenomenon in our knowledge);

2) notion (generalized sensory images of different objects and phenomena);

3) scheme (mental conception of an object or phenomenon, which has a spacecharacter contour);

4) concept (a concept that holds the most common, essential features of an object or phenomenon, its objectively constructed logical characteristics);

5) prototype (categorical concept, which gives an idea of the typical member of a certain category);

6) propositional structure (model of specific areas of our experience, in which elements (arguments and basic predicate, linking these arguments) are distinguished, their characteristics are submitted and links between them are pointed out);

7) frame (multi-concept, which is a "package" of information, knowledge about stereotypical situation);

8) scenario or scripts (dynamic frame which is a sequence of steps, episodes extended in time);

9) gestalt (conceptual structure, complete image that combines the sensual and rational components in their unity and integrity).

There are several other typologies of concepts, which depend on different parameters. For instance, Vorkachev (2004) singles out concepts of higher level (HAPPINESS, LOVE, CONSCIENCE) and conventional concepts. Slyshkin (2004) identifies primary and secondary concepts, metaconcepts (formed as a result of the previous understanding of products of previous conceptualization and which have implemented reflection of native speaker), proportional concepts, concepts that have emerged or emerging, and limiting and rudimentary linguo-cultural concepts. Karasik (2004) distinguishes between parametric and non-parametric concepts (regulative and non-regulative). 
Prikhodko (2008) proposes to consider the types of concepts within such binary oppositions as "parametric" - "non-parametric", "universality" - "specificity", "regulatory" - "non-regulatory", "positivity" - "negativity". Zhabotynskaya (2009) makes logical classification of concepts that takes into account the ostensive and nominal ways of identifying entities. Ostensive concepts are notions, the explanation of which can be given on the basis of appropriate target domain: an image, gestalt and action scheme. Concepts of nominal type are notions, explanation of which can be given only verbally; these are actually notions. The researcher points out that this classification may only be used for those concepts that are marked by morphological, lexical and syntactic units.

Our review of different types of concepts would be incomplete without the approaches presented below, which are based on various principles: personal, age, national and universal concepts (Маслова 2008); language concepts, cultural, linguo-cultural, ethnical and anti-concepts (Степанов 1997). Language concepts are divided into: 1) categorical (time, space) (Ельцова 2000); 2) theosophical (God, life and death) (Belekhova 2013; Guzii 2014); 3) teleonomic (truth, justice) (Волошина 2013; Приходько 2008); 4) anthropoconcepts (mother, woman, man) (Бондаренко 2005); 5) emotional (anger, joy, love) (Вежбицкая 1996; Bierwiaczonek 2002; Kövecses 1990; 2000; Panasenko 2012); 6) moral-ethical (patriot, criminal) (Горобець 2007; Гудков 2016). There are also textual (Кагановська 2002; 2003) and literary (Аскольдов 1997; Ніконова 2008; Ніконова 2008а; Davydyuk 2014) concepts; simple (expressed by one word) and complex (expressed by phrases and sentences); verbalized and non-verbalized concepts; abstract and concrete (Попова, Стернин 2010) and many others.

Although we have already presented many interesting studies dealing with concept we can't but mention the following works by outstanding scholars who highlighted principles of subdivision and role of linguo-cultural concepts (Карасик, Стернин 2007; Левицкий 2013; Степанов 2007; Wierzbicka 1992). Perspectives, problems and 
achievements in conceptology are presented in the analytical review written by Vorobyova (2013) and in the collective monograph Conceptual linguistics: Perspective tendencies: monograph (Levitsky, Potapenko, Nedaynova (eds.), 2013).

Radziievska (Радзієвська 2010: 243) identifies five functional properties of the concept in the language that are caused by the genesis of the concept and peculiarities of its functioning in the language and culture: 1) to act as source domain of certain discursive practice; 2) to be accumulator of culturally significant meanings; 3) to function as a means of interpreting reality; 4) to act as cultural scenario and 5) to act as determinants of psycho-mental state.

\subsection{Literary/textual concepts}

In our research, we pay attention primarily to the literary (Askoldov, Nikonova, Ogneva, Tarasova and others) and textual (Kaganovska) concepts that, according to Nikonova (2008), got into focus of cognitive semantics of the literary text a long time ago. Textual concepts are described in the works of Kaganovska $(2002,2003)$ as dual entities, integrating verbal and mental aspects. Speech aspect of textual concepts is a manifestation of their verbal nature, and in this case the concepts are presented as reality, reflected in the mind, not directly but through language. In mental aspect, textual concepts are considered to be images, where certain culturally-conditioned notions about the world are embodied (Кагановська 2003: 3). Textual "vertex" concept or megaconcept branches out subordinate mezoconcepts, macroconcepts, cataconcepts and their conceptual components - thus forming a kind of pyramid hierarchy of metaimages in the literary text. Textual concepts are characterized by semantic tension and ellipticity, which indicate a set of features in the literary text (Кагановська 2003: 21).

The term "literary concept" was introduced by Askoldov in 1928 to describe the basic unit of individual author's consciousness, which reflects the result of a complex process of interpreting the real world by poet or prose writer. Askoldov writes (Аскольдов 
1997: 275-276): "Literary concepts are figurative, symbolic; ...they tend primarily to the potential images and also direct to them the same way as cognitive concept directs to specific idea within its logical generic volume".

The literary concept as any other concept has mental nature, cultural essence and is characterized by dynamic and mostly verbal representation. Originality of the literary concept lies in its psychological complexity, blurring, and literary imagery (Askoldov 1997). Exploring the literary concepts as basic units of individual author's worldview, researches argue that literary concepts differ from the cultural and language concepts in terms of content, expression, structure and volume. In particular, if language concept is a quantum of information about the world, stored in the memory of a native speaker as verbal substrate (while the cultural concept structures culturally conditioned native speakers' notions of world), then notions, ideas, emotions, feelings, author's volitional acts, his/her world outlook, caused the author's worldview and specific genre of literary text are being sublimed in the literary concept (Ніконова 2008). The content of linguistic and cultural concepts is variable and constantly enriched by new conceptual characteristics; the scope of the literary concept is fixed (Ніконова 2008a: 183).

Ogneva considers the literary concept as a component of conceptual sphere, which includes those cognitive signs and the phenomena of life that are saved by the historical memory of the people and exist in writer's mind as cognitive-pragmatic topics in plot development, which create cognitive aura of the literary text (Огнева 2010). The researcher proposes to distinguish literary concepts by three factors: 1) the semantic content: basic concepts of art and culture; 2) the way they function in language: fading concepts, appearing concepts and actualized concepts; 3) the type of knowledge representation: frames, scenes, scenarios, cognitive maps, etc. (Огнева 2011).

Thus, the concept is a complex mental framework that has a multi-layered structure, all the layers of which are the results or remains of culture of different eras. The concept reflects human's knowledge of the world, the image of the world, which in turn reflects 
the human's vision and perception of reality. There are different approaches to the study of concepts and different kinds of concepts - from universal to literary. Concepts are modelled in a different way and have different structure formation. In our research, we consider the literary concepts, embodied in writings of the famous American writer Ray Bradbury, that is why the next part of this article we focus on characteristic features of his works.

\section{Features of Ray Bradbury's (scientific) fiction}

Unusual, unique, unordinary - one can say about the outstanding works of American writer Ray Douglas Bradbury. When a reader takes into hands his novels or collection of short stories, (s)he is always surprised by his non-standard manner of writing: a reader can fly in a time machine with his characters in distant future or step into another world, conquer the forces of evil or fight against the enemies. Over a lifetime, Bradbury published more than eight hundred different works: novels, stories, essays, short stories, poems and plays (Биография и творческая деятельность, s.a.). The first book that brought him fame was "The Martian chronicles", which, in fact, was a collection of short stories, united by a common theme - the history of Mars exploration by people, the fate of the former inhabitants of the planet, and most importantly - the fate of ordinary people caught up in difficult situations. "Martian" theme will always be important for the writer - the "Martian" cycle includes many short stories, such as: "The concrete mixer", "Dark they were, and golden eyed (the naming of names)", "The strawberry window", "The blue bottle", etc. After this collection there were published two more books, which are the most famous nowadays - dystopia novel "Fahrenheit 451 " and partly autobiographical novel "Dandelion wine". But Bradbury's talent as a writer was most powerfully manifested in the genre of short stories. Hundreds of short stories written by him are included in such collections, as: "Dark carnival", "The illustrated man", "The golden apples of the sun", "The October country", "A medicine for melancholy", "R is for rocket", "The machineries of joy", "S is for space", "I sing the body electric", "Long after midnight", "A sound of thunder", etc. 
Bradbury's works have been investigated by many literary critics and researches, such as Bilomlynska ("The old man and old woman"), Anyutyn ("Reality of fantastic world"), Oganyan ("On the trace of one man"), Risova ("Dear Mr Bradbury"), Khmara ("One last story"), Stephen King (chapter from his book "Dance of Death"), Zasursky ("Ray Bradbury as a person and writer"), Hosyzina ("American dream VS American dreamers") (Безниско 2003), Panasenko - articles "Biblical motifs and allusions in short stories by Ray Bradbury" (Panasenko 2013) and "Topofone in works by Ray Bradbury" (Панасенко 2013a).

Bradbury easily changes the style and genre of his works. In the stories written in the same year one can find science fiction, melodrama, detective and fantasy, historical sketches, poems and others. That is why in Bradbury's works protagonists burn books ("Fahrenheit 451"), travel through time ("The fox and the forest"), irrepressibly fall in love ("A medicine for melancholy" and "The great fire"), meet with mermaid ("The shoreline at sunset") or prehistoric animals ("The fog horn") and line up in a queue to pay money for the spit in Leonardo's Mona Lisa ("The smile").

Bradbury tests "reasonable person" by unexpected and paradoxical exams, prompting to choose: dark-light, war-peace or love-hate. The heroes of Bradbury's stories - are minded, controversial and extremely active people: fantastic frame is usually only a background for the development of purely human dramas (Безниско 2003).

Bradbury's world is evaluated by many researchers as "the world of a romantic who is in love with the immensity of the universe and firmly believes that the most important thing in it is the human being himself" (Безниско 2003). Some American fiction critics considered Bradbury as a fighter against social injustice; others considered him Master of Science fiction, and many others - a pacifist who is very far from the realities of life. Literary critic Butyakov called Bradbury "Martian from Los Angeles"; he emphasized on Bradbury's very specific features of lifestyle and personal qualities: "How can we explain that the person living in industrialized America in $20^{\text {th }}$ century, 
has never flown on an airplane, had never had a car and generally preferred bike. He has not graduated from the university, but he has a truly encyclopaedic knowledge" (Бутяков 2000: 5).

Bradbury's humanistic philosophy is clearly manifested in his short stories - the vitality that filled the protagonists' soul with humanistic feelings, their ability to resist injustice, backwardness, evil, and desire to help people and catch up with any of the great dream and make it real, help them fight with reality, openly hostile to humanity. The author was also well aware of the natural death - it is only one of the life's sides. Human lives until there is the world and the world is until there is human who sees and appreciates it: "No person ever died that had a family" (Bradbury 2003). This axiom, which is found in Bradbury's "The leave-taking", should be seen as another evidence of the author's belonging to the humanistic philosophy.

Bradbury's main problems concerning humanity are a conflict between human and technology and a conflict between human and nature. The first conflict - human and technology - is traced in many short stories and in novel "Fahrenheit 451"; some critics even accuse Bradbury of prejudices against technology - of "technophobia". In "Fahrenheit 451" there are two symbols of humanity "mechanization". The first is a "mechanical dog" - cyber designed for catching "criminals" who knocked out the system. The second is the modernized TV. The mechanical dog represents the totality, repression; it recalls the punishment for disagreeing with the community for trying to break out of the track. Television Wall is a symbol of human indifference, atrophy of the soul and future human intelligence (Шлионская, s.a.). In "Veldt", the mechanized room is, on the one hand, a brilliant work of art, on the other - terrible illusion that becomes a reality (Макарова, Бочкарёва 2008). The same theme is described in "Marionettes, Inc.", "The city", "The pendulum", "The toynbee convector" and so on. Bradbury expressed concern that the development of technological advances would make people lonely, life useless because machines will replace the functions of people not only in manufacturing but also in the family (Сибирцева 2014). Human feelings - 
joy, sorrow, hate, friendship, conspiracy, tears, laughter, desire to enjoy beautiful or destroy it - cannot be explained by the computer's actions. Spiritual and moral values help people be better, more humane and love others. The writer stresses that when we cease to love, feel, help others, cry, jump for joy - we act as machines (Безниско 2003).

The second conflict experienced by humanity is the conflict between human and nature. In Bradbury's works, nature is understood as a source of life, on the one hand, and the source of death - on the other hand. The author draws parallels with the natural world, which reflects the complexity of human existence; the realization of the LIFE and DEATH concepts is revealed in their interdependence and correlation. This is emphasized by the author's words from his own book about the power of nature: "to remind people that we're allotted a little space on earth and that we survive in that wilderness that can take back what it has given, as easily as blowing its breath on us or sending the sea to tell us we are not so big." (Bradbury "Fahrenheit 451" 2013: 72). As the source of all beginnings, nature gives life to human; as a living being human has certain characteristics, such as age, that Bradbury shows in the opposition of youth (children) and old age (the elderly) and in the description of characters' appearance - the writer reveals human essence mainly through eyes, face and hands. Unlike animals, human has the ability to feel and can develop this feeling. The brightest emotions, inherent in human and described by the author are fear and overwhelming happiness.

However, living among other people, human can't help developing as a social being that knows how to create and interacts with anyone or anything. This is a negative impact on the environment and on human itself; it is reflected in the unrestrained pursuit of progress in science and technology, when such creations, as city and cars, made by man, enslave the human. Yet, despite these aspirations, human is still very close to nature and interacts with it, when nature acts as a teacher for a human and sometimes a kind of quiet harbour and source of human's energy. From the start, giving life to human, nature constantly accompanies the human throughout life, sometimes explicitly, sometimes as an invisible observer, ready in any moment to help. 
But sooner or later the humans die, go back to their origins - Nature. However, in this eternal natural cycle one thing remains unchangeable - life, which according to Bradbury, with all its pros and cons, is the main value. Based on the analysis of Bradbury's worldview, it should be noted that the concepts in his works are not isolated from each other, but are combined. This connection helps better understand the author's perception of life and the world, based on the assumption that life is a unified whole, all elements of which are closely interconnected, yet human with his/her ability to feel, experience and change acts as a link in this system (Литвинова 2009).

In Bradbury's world there are constant images, moving from story to story, which can be called symbols: these are four elements (Fire, Water, Earth, Air) (Маркина 2006). Bradbury's characters are constantly struggling with these four elements. The analysis of Bradbury's works shows that the most distinguished elements among them are FIRE and WATER. That is why for our further research we have chosen these two elements, which represent not only the FIRE and WATER concepts, but are also known as global symbols important for our life. To understand better the meanings conveyed by these concepts we shall describe their symbolism. Difference between concept and symbol will be presented below with the help of illustrative material and in tables 1 and 2 .

\section{Symbols Fire and Water}

The symbol is known to humanity since ancient times as a mark or a cognitive sign (Аверинцев 1999), composed of two halves of a coin or of a medal (Eco 1986: 130). Today symbol functions as cognitive and cultural category that exists in the text and from which the text can be unfolded - that is a global symbol and a symbol that exists only within the text and is understood as a symbol only in a certain literary context, i.e. text symbol (Арутюнова 1990; Лотман 1996; Шурма 2008; Есо 1986).

In literary texts, global symbols are not created by the writer, but rather are chosen by $\mathrm{him} / \mathrm{her}$, consciously or unconsciously, from cultural material available in the author's 
thesaurus in his/her conceptual image of the world (Шурма 2009). Lotman (Лотман 1996: 123) argued that:

"Symbolic "alphabet" of any poet is not always individual: he can draw his symbols from the arsenal of the era, cultural orientation, and social circle. The symbol is associated with memory culture, and a whole range of symbolic images vertically permeates the history of mankind or its large areal layers. The individuality of the artist is evident not only in the creation of new occasional symbols (finding symbolism in non-symbolic reading), but also in updating sometimes very archaic symbolic images. However, the most significant system of relations are those, where poet establishes between the main images and symbols. The area of symbolic definitions is always ambiguous. Just forming a crystal lattice of mutual relations, they create that "poetic world", which is a particular feature of the artist".

Thus, the same global symbol can be unfolded in different plots, and this process is unpredictable, as the global symbol has memory older than the memory of the text in which it unfolds (Лотман 1996: 148). We consider two elements of nature - fire and water as global symbols, which are widely represented in Bradbury's (science) fiction.

\subsection{FIRE Symbol and its meanings}

Fire symbol is common in many cultures of the world, for the first victory of primitive man - taming of fire - has marked itself the beginning of civilization. Fire is the only one of all elements that human can reproduce himself with the help of available means, so it can really serve as evidence of the divine origin of human (Grief, s.a.). Fire as well as water has different definitions and interpretations, the concise digest of which we present below using the most popular dictionaries of symbols:

\section{A) The complete dictionary of symbols by Tresidder}

Fire is a divine energy, clarification, revelation, transformation, rebirth, spiritual impulse, temptation, ambition, inspiration, sexual passion; strong and active element that symbolizes both creative and destructive forces. Graphically fire in alchemy is depicted as a triangle $(\Delta)$ considered as a substance that brings together three other 
elements: Earth, Water and Air. At a household level, fire is a protective and calming image of hearth. However, it can be also destructive and threatening force of nature (Тресиддер 1999).

Dual feelings: fear and reverence are underlying the rituals of fire worship. In ancient and primitive cultures fire was worshiped as God himself, and later - as a symbol of divine power. In ancient times, fire was considered to be a living creature that eats, grows, dies and then is born again; these signs suggest that fire is the earthly incarnation of the sun. Due to the role that fire played in people's lives in most mythological traditions, it was considered to be the result of divine activity. In those traditions, where fire was not the direct subject of worship, it still played an important role as a powerful symbol of divine phenomena, such as fire in Christianity, where it is considered the embodiment of the Holy Spirit. In the culture of the North American Indians, fire was revered as a manifestation of the Great Spirit ${ }^{1}$; they consider fire as a symbol of happiness and prosperity and called the sun the Great Fire. In Buddhism pillar of fire is a symbol of Buddha and firelight - is a metaphor of wisdom.

In Christian art, fire is the highest test of virtue and faith; burning heart - is the emblem of some saints, such as St. Augustine and St. Anthony of Padua. Confidence that fire can cleanse from evil led to the atrocities of the Inquisition in the Middle Ages. The symbolism of fire associated with the resurrection is personified by images of Phoenix bird and salamanders; it appeared in Easter rituals of the Roman Catholic and in the Orthodox churches: during these rituals candles are solemnly extinguished and later are lit again by the "new fire" (Тресиддер 1999).

At the heart of the symbolism of Eternal Flame, there is concern for the preservation of hearth; it had a huge significance from ancient times. The symbolism of fire related to sexuality (fire is a metaphor for sexual desire) is based on the ancient technique of obtaining fire by means of friction (Тресиддер 1999). 


\section{B) A dictionary of symbols by Cirlot}

The Chinese in their solar rites utilize a tablet of red jade, which they call Chang; it symbolizes the Element of fire. In Egyptian hieroglyphics, fire is also related to the solar-symbolism of the flame, and is associated in particular with the concepts of life and health (deriving from the idea of body-heat). It is also allied with the concept of superiority and control, showing that the symbol had by this time developed into an expression of spiritual energy. The alchemists retained in particular the Heraclitean notion of fire as "the agent of transmutation", since all things derive from and return to fire. In this sense, being a mediator between forms, which vanish and appear fire, is

like, water, a symbol of transformation and regeneration... Fire embraces both good (vital heat) and bad (destruction and conflagration). It implies the desire to annihilate time and to bring all things to their end (Cirlot 2001).

\section{C) A dictionary of literary symbols by Ferber}

Fire is very important to human life. As it comes in various forms - the sun and stars, lightning, volcanoes, sparks from flint, burning logs in a hearth, candles, oil lamps, conflagrations of a city or forest, its symbolic meanings in literature are as manifold as the forms a flame may take... The meanings of fire are not only manifold but sometimes ambiguous: what warms can burn, what illuminates can dazzle and blind. Fires are found on earth, in heaven, in hell, and in purgatory; they bring life and death; they can kill by burning up or by burning out. In literature, it has a few senses: the fire of the Lord in the Bible, the fire of purgatory, the Promethean fire of culture or intellect, and the fire of passion (lust and anger) (Ferber 1999).

\subsection{WATER Symbol and its meanings}

WATER as one of the fundamental elements of the universe, is the primordial, initial state of all things (Аверинцев 1999). The main meanings of WATER are as follows: 


\section{A) The complete dictionary of symbols by Tresidder}

Water is the ancient universal symbol of purity, fertility and the source of life itself. In all known legends about the origin of the world, life emerged from the firstborn water, the female symbol of potency, devoid of form. In general terms, water is the emblem of all liquids in the material world and the fundamental circulations (blood, juice plants and seeds), dissolution, mixing, adhesion, birth and rebirth. It was believed that pure water, especially dew, spring and rainwater had medicinal properties and were the forms of God's grace, the gift of mother earth (spring water) or heavenly gods (rain and dew). Deference to fresh water as an element that cleans is especially characteristic of religious traditions of those countries, where water supplies are scarce. This is shown by Jewish, Christian and Indian rituals of purification or baptism. Baptism combines cleansing, solvent and fertile properties of water, wiping out sins and birth of a new life. Water is also compared to wisdom; in Taoism image of water that finds a way to bypass obstacles, is a symbol of the triumph of the apparent weakness over the force. Tireless water is a Buddhist symbol of the rapid flow of life (Тресиддер 1999).

\section{B) A dictionary of symbols by Cirlot}

In Egyptian hieroglyphs, the symbol for water is a wavy line with small sharp crests, representing the water's surface. The same sign, when tripled, symbolizes a volume of water, that is, the primeval ocean and prime matter... In the Vedas, water is referred to as the most maternal because at the beginning everything was like a sea without light. In India, this element is generally regarded as the preserver of life, circulating throughout the whole of nature, in the form of rain, sap, milk and blood. Limitless and immortal, the waters are the beginning and the end of all things on the earth. Water is, of all the elements, the most clearly transitional, between fire and air (the ethereal elements) and earth (the solid element). By analogy, water stands as a mediator between life and death, with a two-way positive and negative flow of creation and destruction (Cirlot 2001). 


\section{C) An illustrated encyclopaedia of traditional symbols by Cooper}

Water is the source of all things in the universe, the symbol of primary matter. Any water is a symbol of the Great Mother and is associated with birth, feminine, prima material, the source of life. Water is also compared to the continuous change in the material world, unconscious. Water dissolves, destroys, purifies, "washes away" and restores. Immersion in water symbolizes not only a return to the original state of purity, the death of the old life and the new renaissance, but also ablution of the soul in the material world.

Water and fire are opposing elements, which ultimately penetrate into each other and unite, symbolizing the contradictions of the material world. Fire and water are also associated with two great principles, the Father-Sky and Mother-Earth, moreover the Father-Sky turns into rain that is poured on the ground. The Chinese water belongs to Yin, month beginning and is symbolized by trigram Kan; fire is a symbol of Yang power and solar beginning.

Thus, Fire symbol is one of the four elements, which has the following basic meanings: life force, hearth, divine energy, clarification, revival, seduction, inspiration, sexual passion, eternity, transformation, invisible energy, etc. Water symbol is the primary element that creates all life; water has such features as clarification, restoration, and revival. It symbolizes wisdom, wellfare and spiritual life. Both symbols are dualistic in their nature (fire - revives and destroys; water is a two-way flow (positive and negative) of creation and destruction). Both symbols are antithetical and inseparable at the same time, because they penetrate into each other and symbolize the contradictions of the material world (Купер 1995).

Above we have presented digest of several dictionaries of symbols, because information presented there is very important for better understanding Bradbury's works, which abound in different symbols. To decode additional information hidden in his texts the reader should have a definite sum of knowledge especially of cultural- 
specific character. Fire and Water, in our opinion, are universal symbols because they exist absolutely in all cultures and religions of the world. FIRE and WATER are also the basic concept-elements, embodied in Bradbury's works; moreover, each element can have "male or female face". Such an interpretation of these symbols exists in the Chinese philosophy of life, where water, as we have noted above, is presented as Yin and fire is presented as Yang. Let us briefly consider the Chinese philosophy of Yin and Yang.

\subsection{Yin and Yang}

In ancient mythology, dark beginning (Yin) and light beginning (Yang) have always been paired. Originally Yin meant shady (north) side of the mountain. Later, Yin became a symbol of femininity, north, darkness, death, earth, moon, even numbers, etc. Yang, originally meant light (south) side of the mountain; later became a symbol of masculinity, south, light, life, sky, sun, odd numbers, etc. (Рифтин 1991). Currently, Yin and Yang are interrelated concepts of ancient Chinese philosophical school of Taoism and Chinese symbols of double distribution of forces, including active or male principle (Yang) and passive or female principle (Yin).

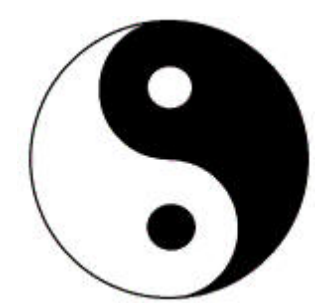

Figure 1. Chinese symbols Yin and Yang

It has the form of a circle, divided in two lines that are reminiscent of Sigma. These two parts, formed in such a way, acquire dynamic intentions, which do not happen when the distribution is carried out through diameter (See Fig. 1). Light half represents Yang power, and dark - Yin power, but each half includes circle, cut from the middle of the opposite half, thus symbolizing the fact that each of the modes should contain the germ of its opposition (Грицанов, s.a.). 


\section{Research methodology of the literary concepts FIRE and WATER in Bradbury's (science) fiction}

To analyse the FIRE and WATER concepts we used one of the most common methods of investigating concepts, presented in the works of many scholars, namely in the works of Russian and Ukrainian scholars, such as Izotova (2009), Karasik (2004), Maslova (2008), Ogneva (2013), Vorkachev (2004) and others. This methodology assumes that there are three basic components in the concept structure: notional, image- and sensebearing. The first, notional component contains the information that reflects its information essence as a number of definitional features (Воркачёв 2004; Карасик 2004; Маслова 2008). The description of the notional component is realised via the analysis of the semantic structure of the main lexemes, which represent concepts in the language and is based on the componential and definitional analyses of these lexemes (Ізотова 2009). The image-bearing component is identified through the reconstruction of various metaphorical schemes, mainly conceptual metaphors (Lakoff \& Johnson 2003). This method allows covering and bringing into focus some signs of target domain through understanding it in terms of source domain. Sense-bearing component is created by the system of semantic attributes highlighted on the basis of componential analysis of lexemes, which describe source domains as a part of metaphorical conceptual schemes (Ізотова 2009, Ніконова 2008). We do not share Prokhorov's opinion (2009: 46) that concept is a set of myth, symbol and sign. Concept has imagebearing component; some concepts as FIRE, WATER, MIRROR, SKY, etc. may be a part of the myth and in some cultures may be symbols. Such concepts, as, say, HONESTY, CRIMINAL, PATRIOT, etc. have no symbolic character.

As far as our aim is to do an integrated analysis of two literary concepts, we would like to trace what images are created when FIRE and WATER are combined in the same text; what additional interpretation of these images can be done using a psycholinguistic approach and singling out light, active, dark, sad, merry, beautiful and complex texts (Белянин 2000); how Chinese philosophy (namely active or male principle (Yang) 
associated with fire and passive or female principle (Yin) associated with water) has influenced Bradbury's fiction.

A case study of our research is 50 short stories written by Bradbury and a novel "Fahrenheit 451".

\section{The literary FIRE concept in Bradbury's (science) fiction}

The FIRE concept is widely represented in Bradbury's works; in addition, this element takes a central place in his works. Bradbury touched upon the fire theme in many stories and utopian novel "Fahrenheit 451" finally showed the writer's love of the subject. The results of detailed analysis of this novel and numerous short stories are presented below.

According to the plot of this novel, books are outlawed and are burned in a fire by special firemen. Considering fire as a symbol in this novel, we can identify two opposite elements in its aspect: fire that builds - "the spirit fire" and fire that burns - a destructive energy. Both of these elements are presented in Bradbury's "Fahrenheit $451 "$ ". Burning as a constructive energy and burning as an apocalyptic catastrophe are symbolic poles of this novel that reveal the symbolism of fire through a complex and bifurcated nature of man as a creator and as a destroyer. It contains the key to the understanding of the whole work that gives the narrative integrity and sharp depth (Шлионская, s.a). This novel grew out of five stories that Bradbury would later call "five crackers": "The bonfire", "Bright phoenix", "The exiles", "Usher II" and "The pedestrian". These short stories touched the topic of censorship, banned books, book burning, strength, individuality or rescue of art from the clutches of those who could destroy it. They all belonged to the genre of social satire and turned to matters especially close to Bradbury (Рэй Брэдбери, s.a.).

The FIRE concept is also manifested in such stories, as "The golden apples of the sun", "Embroidery", "The great fire", "Happiness machine", "Internal in sunlight", "The 
scythe", "The burning man", "Fire balloons", "The dragon "," The little mice"," The million-year picnic", "The fever dream ","Pillar of fire ","Kaleidoscope ","Touched with fire", "Bright phoenix", "The exiles", "Embroidery" and others. Using the abovementioned methodology, we can single out three basic components in concept FIRE: notional, image- and sense-bearing.

Thus, the notional component of this concept has such basic meanings, as: 1) heat, light, and flames that are produced when something burns; 2) an event when something burns in a way that causes damage and cannot be controlled; 3 ) a pile of wood, coal, etc. that is burning to produce heat; 4) the shooting of guns and other weapons; 5) flames that destroy things; 6 ) emotion; 7) heating equipment (CLD, LDCE). ${ }^{2}$ Based on these dictionary definitions, we can say that notional component has such basic meanings, as "flame", "heat", "event", "to burn", "to damage", "to destroy".

The image-bearing component contains the information of connotative and associative plane (Тарасова 2010). The FIRE concept in Bradbury's works has different images - from the image of human, animal, artefact to the image of destructive force that brings death. For graphical illustration of this concept, we have chosen triangle $\Delta$ as one of the possible symbols, which was used by alchemists (Тресиддер 1999).

In "The golden apples of the sun" the basic conceptual metaphor, which is actualized is SUN - IS $\triangle$ FIRE (For now there was only the sun and the sun and the sun. It was every horizon, it was every direction. It burned the minutes, the seconds, the hourglasses, the clocks; it burned all time and eternity away ... it burned sleep and the sweet memories of sleep and cool nightfall), where $\triangle$ FIRE - IS A CUP filled with a PIECE OF SUN (and here is our cup of energy, fire, vibration, call it what you will, that may well power our cities... Here, from this cup, all good men of science and religion: Drink! Warm yourselves against the night of ignorance, the long snows of superstition, the cold winds of disbelief, and from the great fear of darkness in each man); there are also such images as $\triangle$ FIRE - IS A CUP OF GOLD (The heart of the 
ship rushed, beat, rushed, the Cup of gold in it); $\Delta$ FIRE - IS A YELLOW SPOT (And the tribe crept at last, trembling, near the fire, and they put out their flinching hands and felt the new season in their cave, this small yellow spot of changing weather); and $\triangle$ FIRE - IS A GIFT from God (a million years ago a naked man saw lightning strike a tree ... with bare hands he plucked a limb of fire ... And the gift of fire was theirs).

In "The burning man", the main character is a man of sun, who has a typical appearance (bronzed body to the waist, his hair ripened to wheat color by July, the man's eyes burned fiery blue in a nest of sun wrinkles) and is born as a result of extreme heat (What if the intense heat, I mean the really hot hot heat of a month like this...just baked the Ornery Man). In this example, three conceptual metaphors are actualized: A HUMAN BEING - IS AN OBJECT OF INANIMATE NATURE (MAN - IS SUN) as part of the conceptual structure GREAT CHAIN OF BEING (Lakoff \& Turner 1989; Turner 1996), presented in reverse perspective; SUN - IS $\triangle$ FIRE and AN OBJECT OF INANIMATE NATURE - IS A HUMAN BEING ( $\triangle$ FIRE - IS A MAN). Bradbury describes man-sun like a lion (the creature in the back, with his great lion ruff of hair and mint-fresh yellow eyes... Neva gave a quick, critical look at the lion, the intruder in the back seat, to see if she could shut his jaws with a glance. They shut), generating another conceptual metaphor associated with GREAT CHAIN OF BEING - A HUMAN BEING - IS AN ANIMAL. Since FIRE is a HUMAN BEING (MAN) in this story, we can reconstruct one more conceptual metaphor AN OBJECT OF INANIMATE NATURE - IS AN ANIMAL ( $\triangle$ FIRE - IS AN ANIMAL). However, the main image of FIRE in this story is $\triangle$ FIRE - IS A HUMAN BEING.

In "The happiness machine", fire is presented as an explosion: $\triangle$ FIRE - IS AN EXPLOSION (Fire is muffled explosion); in "The scythe" file kills the protagonist's family ( $\triangle$ FIRE - IS DEATH) in human form ( $\triangle$ FIRE - IS A HUMAN BEING) (Something shot up over the hill into the sky. It was like a living thing, with arms of red color, licking at the stars. Sparks fell into his face. The thick, hot odor of fire came with it. The house! The little white house with the live oaks was roaring up in one 
savage bloom of fire. No one screamed inside. No one ran around or shouted). In "The fire balloons" FIRE is shown through the image of balls that have soul and memory and can talk to human; they even were men in the past ("But globes of fire"! ...these fiery spheres have souls... Oh, the memory of those lovely Fire Balloons... "You see?" said Father Peregrine... They know. They understand. They are not animals... So very long ago we became these things that we now are. Once we were men, with bodies and legs and arms such as yours). Such idea is expressed by conceptualized structure $\triangle$ FIRE - IS A HUMAN BEING.

In "The dragon", where the train is depicted as a dragon that has eyes made of fire (The night train, in fire and fury ... This dragon, they say his eyes are fire. His breath a white gas; you can see him bum across the dark lands. He runs with sulphur and thunder), the conceptual structure is AN OBJECT OF INANIMATE NATURE - IS AN ARTEFACT ( $\triangle$ FIRE - IS AN ARTEFACT). A similar image of FIRE can be found in "Bright phoenix", where, according to the plot, books were burned in incinerators; this actualizes such structure, as $\triangle$ FIRE - IS AN ARTEFACT (INCINERATOR) (We crossed the green lawn where a huge portable Hell was drawn up hungrily, a fat black tar-daubed own from which shot red-orange and gaseous blue flames into which men were shoveling the wild birds, the literary doves which soared crazily down to flop broken-winged, the precious flights poured from every window to thump the earth, to be kerosene-soaked and chucked in the gulping furnace). Since this incinerator is equated to a person who was devouring books with an appetite and had stomach (The Baal incinerator rumbled its appetite, spark-burned the lawn. Barnes stared full at the blind yellow-red sun in its raving stomach), we can assume that INCINERATOR - IS A HUMAN BEING; a personification of artefact (incinerator) again leads us to the overall conceptual metaphor $\triangle$ FIRE - IS A HUMAN BEING.

In "Fever dream", the disease (high fever) captured the body of the main character - a little boy and almost "ate" it (The disease had eaten his body and from the eating had 
reproduced itself in feverish duplicate). Thus, the heat that is associated with a personified fire, allows us to reconstruct conceptual metaphors, such as $\triangle$ FIRE (FEVER) - IS A HUMAN BEING and PHYSICAL AND EMOTIONAL STATES ARE ENTITIES WITHIN A PERSON (Lakoff \& Johnson 2003: 51). At the peak of his illness the boy became a man who breathes fire; it actualizes the inverse conceptual metaphor HUMAN BEING - IS $\triangle$ FIRE (Now the warmth was stealing up his neck, into his cheeks, like a hot wine. His lips burned, his eyelids, like leaves, caught fire. His nostrils breathed out blue flame, faintly, faintly).

In "Pillar of fire", fire brings death: people, who died, were burned in crematoria (In the town, theoretically, thought William Lantry, say you have a dying man. In a moment he will be dead. What happens? No sooner is his pulse cold when a certificate is flourished, made out, his relatives pack him into a car-beetle and drive him swiftly to the Incinerator! That functional finger, that Pillar of Fire pointing at the stars), so fire acquires negative connotations and actualizes such metaphors as $\triangle$ FIRE - IS DEATH and $\triangle$ FIRE - IS A DESTROYER. The same images of fire ( $\triangle$ FIRE - IS DEATH and $\triangle$ FIRE - IS A DESTROYER) arise in "Kaleidoscope", where men due to explosion of the missile, found themselves falling in open space and slowly burning away (The first concussion cut the rocket up the side with a giant can opener. The men were thrown into space like a dozen wriggling silverfish...They fell. They fell as pebbles fall down wells. "Which way are you going?" "It looks like I'll hit the moon." "It's Earth for me. Back to old Mother Earth at ten thousand miles per hour. I'll burn like a match... Tomorrow night I'll hit Earth s atmosphere. I'll burn, he thought, and be scattered in ashes all over the continental lands).

"Million-year picnic" is another story of Bradbury, where the FIRE concept is found: the main characters - a family that fled war on Earth to another planet, Mars. Being on Mars, they arranged a picnic and burned in bonfire all the papers that the head of the family took with him and a map of the Earth, because Earth is lost and they would never come back there (He laid the papers in a clutter in an old courtyard and set 
them afire... He dropped a leaf in the fire. "I'm burning a way of life, just like that way of life is being burned clean of Earth right now... Wars got bigger and bigger and finally killed Earth. That's what the silent radio means. That's what we ran away from". ...Timothy looked at the last thing that Dad tossed in the fire. It was a map of the World). The Fire that burns all the traces of the Earth is the symbol of the REVIVAL; in fact, burning the remnants of the old life, the main character simultaneously renews and regenerates a new life of the earth family on Mars. Thus, FIRE appears as a revival and rebirth ( $\triangle$ FIRE - IS A REVIVAL, $\triangle$ FIRE - IS A REBIRTH) of a new family on a new planet; it also represents the family's hope for a better future ( $\triangle$ FIRE - IS HOPE).

Having analyzed the above-mentioned short stories, we can state that FIRE is mainly represented from the point of view of male ( $\triangle$ FIRE - IS A MAN), because all Bradbury's protagonists in stories above, who somehow relate to the theme of fire, are men - from a little ill boy Charles in "Fever dream" to the captain of a spaceship in "The golden apples of the sun".

Below we give examples of FIRE that represents a female power; these are such stories as "Embroidery", "The great fire" and "Interval in sunlight". In the first story, Bradbury shows three women sitting on the terrace, who are embroidering three different pictures. But suddenly fire arises - it covers their beautiful pictures and burns all around them and even women (But she hadn't time even to lift her head. Somewhere, at the side of her vision, she saw the world brighten and catch fire. She kept her head down, for she knew what it was...they didn't glance about to see what was happening to the country, the town, this house, or even this porch... She watched a fire, in slow motion almost, catch upon the embroidered house and unshingle it, and pull each threaded leaf from the small green tree in the hoop, and she saw the sun itself pulled apart in the design. Then the fire caught upon the moving point of the needle while still it flashed; she watched the fire come along her fingers and arms and body... and at last it found her heart, a soft red rose sewn with fire, and it burned the fresh, embroidered 
petals away, one by delicate one...). The main idea of this story is to show to the humanity (represented by women) that if a nuclear explosion or war occurs on the Earth, it will destroy all that is beautiful on this planet; beauty of life will be removed as embroidery in this story. FIRE is represented as a destroyer and eater of all the beauty ( $\triangle$ FIRE - IS A DESTROYER and $\triangle$ FIRE - IS A DEVOURER) and power that brings death $(\triangle$ FIRE - IS DEATH).

In "The great fire", the main character is a young girl who "burns" with love for the boy (The morning the great fire started, nobody in the house could put it out. It was Mother's niece, Marianne, living with us while her parents were in Europe, who was all aflame. So nobody could smash the little window in the red box at the corner and pull the trigger to bring the gushing hoses and the hatted firemen). "Fire from love" associated with the FIRE concept make it possible to reconstruct such widespread conceptual metaphor as LOVE - IS $\triangle$ FIRE, where fire is a source domain. The fact that the main character was "all on fire" forms the image of a girl who becomes a fire; according to GREAT CHAIN OF BEING such image reconstructs conceptual metaphor A HUMAN BEING - IS AN OBJECT OF INANIMATE NATURE (A GIRL - IS $\triangle$ FIRE).

The third story "Interval in sunlight" is about a couple who came to vacation in Mexico. During the holiday, the woman feels disappointed with her husband, who is always unsatisfied, even with a trip to the volcano. She decides to get away from her husband, and even runs away, but quickly understands that she cannot break up with him and returns. Upon returning, the woman decides that they will go back to the volcano, which is a good fire that will destroy both of them (You know ... we might try the volcano tonight. It looks good. I bet there'll be lots of fire. Yes, she thought, and it will fill the air and fall all around us, and take hold of us tight, tighter, tightest, and then let go and let us fall and we'll be ashes blowing south, all fire.). In this story FIRE is again represented as a destroyer that can destroy a family and love ( $\triangle$ FIRE - IS A DESTROYER) and even bring death ( $\triangle$ FIRE - IS DEATH). As the woman cannot do 
it by herself, she makes projection onto the fire that will rise from the depths of the volcano, burn them and thus will be able to stop her suffering in marriage.

Undoubtedly, Bradbury has such short stories, where FIRE acts as both men and women; for example, "Touched with fire" and "The exiles". In the first story, the main characters - two men, who are engaged in monitoring the potential victims of homicide and accidents, are trying to give these victims psychological support. They decide to save another character - an ill-natured woman - from the murder; since it is very hot weather, and most murders happen when the temperature is high (more murders are committed at ninety-two degrees Fahrenheit than any other temperature). This example leads us to the conceptual structure FIRE, and therefore HEAT, as one of its manifestations, can kill, i.e. $\triangle$ FIRE - IS A MURDERER. At the end of the story the woman who didn't like being followed and being tried to help, almost became a victim of one of the men: through intense heat she feels as if she were in the jungle, which was on fire. The man was almost made to kill the woman with a stick (He was in a blazing yellow jungle. The room was drowned in fire, it clenched upon him, the furniture seemed to shift and whirl about, the sunlight shot through the rammed-shut windows, firing the dust, which leaped up from the rug in angry sparks when a fly buzzed a crazy spiral from nowhere... beyond her on the baked brown wallpaper the thermometer said ninety-two, and he looked again and it said ninety-two, and still the woman screamed... Foxe drew his arm back, cane clenched in fist, very high, and struck.). After this occasion, the ill-natured woman became so angry, that she turned herself to the fire (She spoke with fire and alcohol and smoke). Thus, the main characters - one of the men and the woman, became hostage to extreme heat and anger and turned themselves to the fire. This actualizes conceptual structure connected with GREAT CHAIN OF BEING: HUMAN BEING - IS AN OBJECT OF INANIMATE NATURE and in particular AWOMAN - IS $\triangle$ FIRE.

In "The exiles", FIRE element is also represented by men and women: at the beginning of the story women made fire and performed a ritual dance to stop the arrival of people 
from the Earth on Mars (Their eyes were fire and the breath flamed out... They danced drunkenly on the shore of an empty sea, fouling the air with their three tongues, and burning it with their cats' eyes... Fire bum, and cauldron bubble!). At the end of the story men, who arrived on Mars, made fire to burn the books (The captain stepped forth last. He gave sharp commands. Wood was gathered, kindled, and a fire leapt up in an instant... Firelight limned the faded gilt titles... The captain ripped ages from the books. Leaf by seared leaf, he fed them into the fire. A scream! Leaping back, the men stared beyond the firelight at the edges of the encroaching and uninhabited sea). In both stories, FIRE is a destructive force ( $\triangle$ FIRE - IS A DESTROYER) that brings frustration, anxiety and warnings to people.

Thus, the concept-element FIRE is represented in different ways - from negative images, like devouring fire that kills and destroys people and objects that surround them, to positive images, where fire serves as hope, purification and rebirth (see Fig. 2).

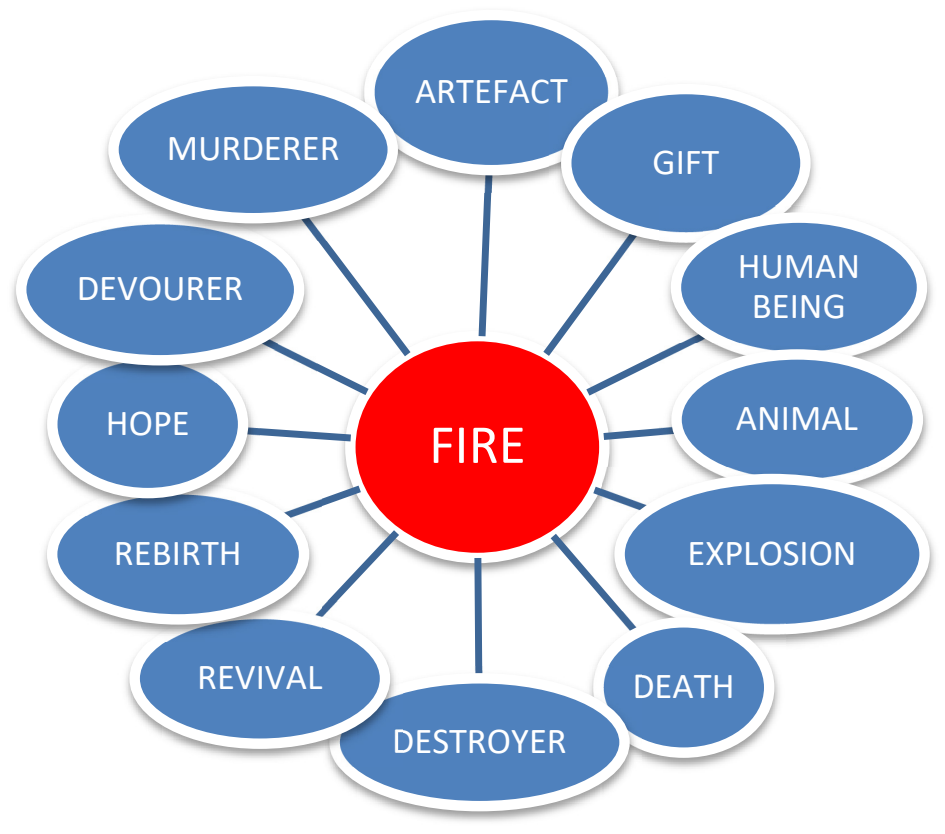

Figure 2. An image-bearing component of the FIRE concept

In general, considering the analyzed fiction, we counted 14 images of FIRE, the most common among them are the images of HUMAN BEINGS (6 cases), the images of DEATH ( 4 cases), the images of DESTROYER ( 3 cases) and the images of artefacts 
(3 cases) (see Fig. 3). In addition to these images, the FIRE concept is presented from the opposite perspective as a source domain for a target domain MAN (4 cases) and ABSTRACT PHENOMENON (SUN in 1 case). Consequently, the most commonly used metaphoric images are such conceptual structures as $\triangle$ FIRE - IS A HUMAN BEING, $\Delta$ FIRE - IS DEATH, $\Delta$ FIRE - IS DESTROYER and HUMAN BEING - IS $\triangle$ FIRE.

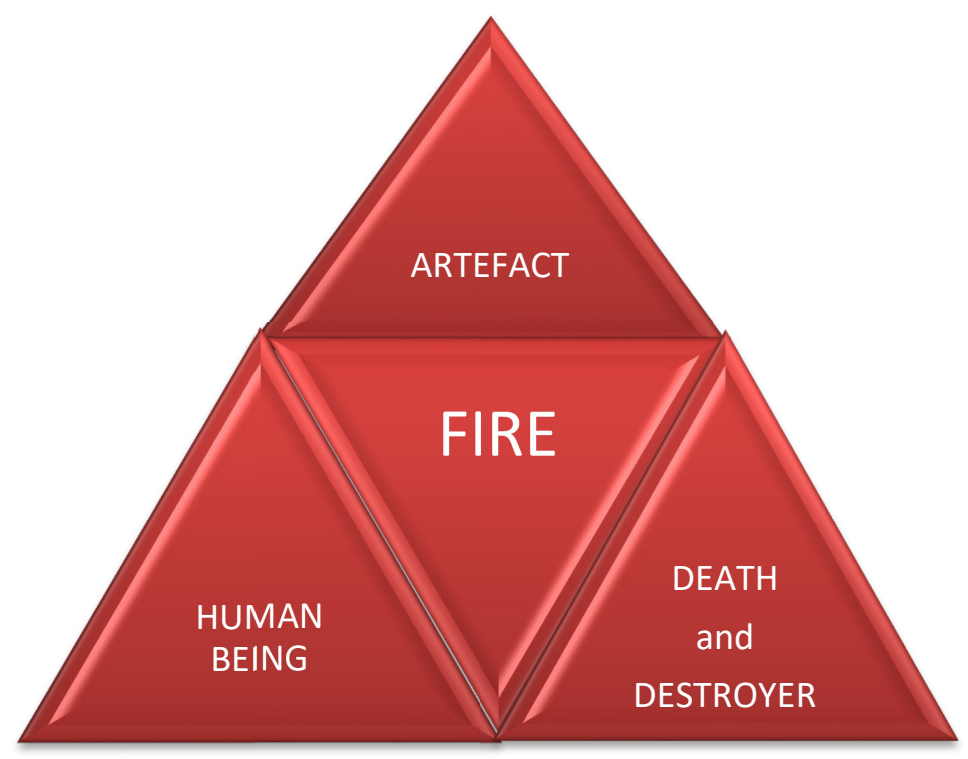

Figure 3. The most common image-bearing components of the FIRE concept

Based on the notional and imagistic layer of this concept, the sense-bearing component consists of lexical units, such as hot, destructive, exploding, renewal, eating. It is worth mentioning that the FIRE concept is often personified and transformed into the image of a human being (usually a man and less common a woman), and vice versa - a human being (male or female) is transformed into the image of fire, which proves our hypothesis that Bradbury implicitly uses Chinese philosophy of life (Yin and Yang) in his works as a base for personification of concept-element FIRE.

\section{The literary ${ }_{A T E R}$ concept in Bradbury's (science) fiction}

Water is one of the favorite themes and elements used by Bradbury in his works. Water, for Bradbury, is often related to the rain, river or sea. In his collections, there are several stories dealing with the rain on Venus, such as "All summer in a day", "The long rain" amongst others. As events in these stories unfold on the planet Venus, this cycle is 
called the "Venusian Chronicles" (Рэй Брэдбери, s.a.). In Bradbury's imagination it is always raining on this planet; this allows for the creation of a very unusual atmosphere and also gives the possibility to try the heroes' characters (Рэй Брэдбери, s.a.). Venus is also considered to be a feminine planet: because Venus is known as the Roman Goddess of love, marriage, beauty, and comfort (Significance of planet Venus, s.a.).

The WATER concept is embodied in stories belonging to other cycles or collection of short stories, such as "The one who waits", "The unterderseaboat doctor", "The leavetaking", "The shoreline at sunset", "The women", "The lake", "The day it rained before", "All summer in a day", "The sailor, home from the sea", "The fog horn", "The long rain", "Yes, we'll gather at the river" and others.

According to dictionary definitions, the notional component of this concept has such meanings, as: 1) the clear liquid that falls from the sky as rain and that is in seas, lakes, and rivers; 2) an area in the sea or in a river or lake; 3) the clear liquid without colour, smell, or taste that falls as rain and that is used for drinking, washing; 4) the surface of a lake, river (CLD, LDCE). Based on these definitions, the notional component is represented by such features as "clear", "liquid", "an area", "sea", "rain", "lake", "the surface of river", "to fall", "to drink".

The image-bearing component is represented by different metaphorical schemes, reconstructed in certain thematic fragments of the above-mentioned stories. To mark graphically the WATER concept, we have chosen a triangle with an inverted apex $(\nabla)$; it is a sign, which the ancient alchemists used to describe water (Тресиддер 1999). Thus, in "The one who waits" and "The unterderseaboat doctor" the WATER concept has features of MAN. The first story begins with a description of an unknown entity, which lives in the well; it cannot move, but it can wait, see the sun, sing songs; it can grieve, it recognizes its old age and pours as rain into the well (I live in a well. I live like smoke in the well. Like vapour in a stone throat. I don't move. I don't do anything but wait. Overhead I see the cold stars of night and morning, and I see the sun. And sometimes 
I sing old songs of this world when it was young. How can I tell you what I am when I don't know? I cannot. I am simply waiting. I am mist and moonlight and memory. I am sad and I am old. Sometimes I fall like rain into the well). However, analysing the last phrase (Sometimes I fall like rain into the well) the reader realises that Bradbury is describing WATER that falls as rain into the well. As WATER has human traits (sees, lives, sings, has age), we can say that the basis of figurative interpretation of the WATER concept is the conceptual scheme $\nabla$ WATER - IS A HUMAN BEING.

According to the plot of the story, WATER destroys three men who flew with the team from the Earth to Mars: at first, men who have tasted water of the well are obsessed by the entity living in it ("How is it, Regent? The water. "Pure as silver. Have a glass"... Now I know who I am. My name is Stephen Leonard Jones and I am twentyfive years old and I have just come in a rocket from a planet called Earth and I am standing with my good friends Regent and Shaw by an old well on the planet Mars...), and then it kills them one by one ("Regent's in the well!" "He must have fallen. Jones, you were here with him. Did you see? Jones? Well, speak up, man." "What's wrong, Jones?" I fall to my knees, the trembling is so bad ..."He's dead," says someone... "Captain, ...you don't look too well, sir...Good God, he's killed himself!"); this actualizes three conceptual schemes at once: HUMAN BEING - AN OBJECT OF INANIMATE NATURE (MAN - IS $\nabla$ WATER) as a part of GREAT CHAIN OF BEING structure, presented in reverse perspective; $\nabla$ WATER - IS DEATH and WATER - IS A MURDERER. The assimilation of WATER to HUMAN BEING is emphasized in the story by the expression (It is called a Soul Well), where the WATER concept and lexeme which denotes it (well) has, like the human, a soul.

The story ends with the same paragraph that was at the beginning (I live in a well. I live like smoke in a well. Like vapour in a stone throat. Overhead I see the cold stars of night and morning, and I see the sun. And sometimes I sing old songs of this world when it was young. How can I tell you what I am when even I don't know? I cannot. I am simply waiting), thus, the author-narrator uses such stylistic device as ring repetition 
that reflects the whirlpool of life and continuous water cycling process. In addition, the use of ring repetition, where WATER is conceptualized, indicates such characteristics of water as its primordial state, i.e. the beginning of all essences (Аверинцев 1999) and the emblem of all liquids and fundamental circulations in the material world (Тресиддер1999).

In "The unterderseaboat doctor", the main protagonist is a psychoanalyst who revealed accidently the secret of his life to a man-patient: his office is a submarine with periscope that floated and submerged below the surface of the water, and the doctor himself is the admiral and the captain of this boat ("Dive! Dive!" "I dove. Thinking that the room might be struck by a titanic iceberg, I fell, to scuttle beneath the lionclaw-footed couch. "Dive!" cried the old man. "Dive?" I whispered, and looked up. To see a submarine periscope, all polished brass, slide up to vanish in the ceiling). Such an interpretation of doctor's office as underwater artefact (submarine) and visits to the doctor as diving into water actualizes the conceptual structure DOCTOR APPOINTMENT - IS DIVING. It is interesting to state that, at the end of the story, the reader finds out that the doctor was a retired captain of the boat; he could not find himself on "the shore" and moved from one "sea" place to another until he moved to New York, because this city was a water island (I moved in stages from the depths to a houseboat, to a wharf bungalow, to a shore-tent and then back to a canal in a city and at last to New York an island surrounded by water, eh? But where, where, in all this, I wondered, would a submarine commander find his place, his work, his mad love and activity?). "Coming ashore," the captain still felt as a part of marine life - he considered himself a jellyfish, octopus and lobster ("It has been no easy thing to come forth on land," he sibilated. "Some days I was the jellyfish, frozen. Others, the shorestrewn octopi, at least with tentacles, or the crayfish sucked back into my skull"). This metaphorical image of a man-fish is embodied in the common zoomorphic metaphor HUMAN BEING - IS AN ANIMAL, where the source domain ANIMALS covers not only the world of animals, but also the world of insects and fish. The image of fish is closely related to the WATER concept: since water purifies and symbolizes a return to 
the source, then fish, respectively, represents the hope for a new birth. The protagonist, imagining himself a fish, was waiting for his revival ashore ( $\nabla$ WATER - IS REVIVAL).

The story "And the sailor, home from the sea" has much in common with "The unterderseaboat doctor", discussed above. Here the main character is a man who, having spent his entire life at sea, builds a house on the land out of the ship, which he used for travelling every day (He got up, swaying, moved to the galley door, opened it, and stepped forth...... onto the porch of a house built like the prow of a ship, onto a porch whose deck was tarred ship's timbers). His beloved died at sea during a storm, having drunk a cup of water from the land (The calm over, one storm began. Another followed. Of the two storms, one ended abruptly - the fever that raged in Kate and burned her to a white dust. A great silence moved in her body and then did not move at all. The sail mender was brought to dress her for the sea.), thus WATER brought death and disappointment: after the death of his beloved the captain left the ship and never returned to it. These metaphorical images reconstruct such conceptual schemes as $\nabla$ WATER - IS DEATH and $\nabla$ WATER - IS DESTRUCTION. At the end of the story, WATER brings death to the protagonist: the captain dies after drinking a glass of water with a typhoon inside (One cup. She was right, Hanks, you know. Not to touch land, ever again. She was right. But I brought her one cup of water from the land, and the land was in water that touched her lips. One cup. Oh, if only ....'He shifted it in his rusted hands. A typhoon swarmed from nowhere, filling the cup. It was a black storm raging in a small place. He raised the cup and drank the typhoon). In addition to the image of destruction, WATER is a force that revives: having sowed "ocean" of wheat, captain, after years of silence, was able again to feel the sound of the sea; being reborn, he began to remodel his home on the ship he sailed all his life (On this land, then, he walked out and cast forth seed, prepared himself for his first harvest and called himself farmer. But one night in that first summer of living as far from the sea as any man could get, he was waked by an incredible, a familiar, sound. Trembling in his bed, he whispered, No, no, it can't be - I'm mad! But ...listen!). The bases of 
such metaphorical interpretation of this concept are conceptual metaphors $\nabla$ WATER - IS REBIRTH and $\nabla$ WATER - IS REVIVAL.

In "The leave-taking", the death of old great-grandmother is portrayed as immersion in warm snow and sea, which waved and drifted her from life shore (Deeper in the warm snow hill she turned her head upon her pillow. That was better. Now, yes, now she saw it shaping in her mind quietly, and with a serenity like a sea moving along an endless and self-refreshing shore. Now she let the old dream touch and lift her from the snow and drift her above the scarce-remembered bed... And the sea moved her back down the shore). The background of this poetic image is a conceptual metaphor $\nabla$ WATER - IS DEATH. The life of this woman is metaphorically described as a river with many curves, floods, lack of water in hot summer: LIFE - IS RIVER ( $\nabla$ WATER). Most of the rivers flow into the sea or the ocean; the old woman's life logically ends on the seashore. Thus, life, like water which brings life, is endless.

In "The fog horn", the concept-element WATER is expressed by the lexeme ocean, which is depicted as a huge SNOWFLAKE that always moves and never repeats its shapes and colors ("The mysteries of the sea" said McDunn thoughtfully. "You know, the ocean's the biggest damned snowflake ever? It rolls and swells a thousand shapes and colours, no two alike"). In "Yes, we'll gather at the river", Bradbury describes a new highway, built near the small town of main characters, as a river of people, metal and light (as that river out there was flowing and there was the great motion and glint and sound of people and metal and light). Verbal poetic images "river of people, metal and light" is based on such conceptual schemes as $\nabla$ WATER - IS PEOPLE, WATER - IS AN ARTEFACT and $\nabla$ WATER - IS LIGHT. The conceptual structure $\nabla$ WATER - IS A HUMAN BEING is reconstructed in the next fragment of the story, where the true voice of water - the voice of the sea -attracts the river to its bank (They listened again. And there, far away, some two hundred fifty or three hundred yards off across a meadow field, nearer the sea, they heard the old, the familiar, but the diminished sound of their river taking its new course, moving and flowing...And 
beyond it, the sound of real water, the sea which might almost have drawn the river to come down along the shore...).

In the examples above, Bradbury's main characters are mostly men who get into different situations connected with water, rain and river. Despite the fact that WATER is considered to be feminine (Yin symbol), Bradbury successfully depicts this element from the male perspective. However, in such stories as "The leave-taking", "The shoreline at sunset", "The women", "The lake", "The day it rained before", or "All summer in a day" the concept-element WATER has an explicitly "female face". Thus, in "The shoreline at sunset" the main characters found on the beach a mermaid (she came out of water, she's lying on the shore...she's got a fish's tail). She had an amazing beauty and was a female pearl (Her face was white sand, with a few water drops shimmering on it like summer rain upon a cream-colored rose. Her face was that moon when seen by day is pale and unbelievable in the blue sky. The mouse was a pale flushed sea-rose... and her neck was slender and white... And as the water shifted her, her skin glinted like a surface of a purl). The lower part of her body shimmered in different colours (The lower part of her body changed itself from white to very pale blue, from very pale blue to pale green, from pale green to emerald green, to moss and lime green). This pearl woman was the real Sea itself (...pearl woman, woman of a whiteness, made of cream-water and clear sky... The woman was the sea, the sea was the woman). The appearance of this amazing creature actualizes such conceptual structures as A WOMAN (MERMAID) - IS PEARL from sea depths and HUMAN BEING - IS AN OBJECT OF INANIMATE NATURE (A WOMAN - IS $\nabla$ WATER).

The story "The women" has the reverse image of water-female: Bradbury shows the sea as a creature with female characteristics (it was of the sea. And being of the sea it was - feminine... it had a woman's ways, the silken, sly and hidden ways. It moved with a woman's grace). The personification of the element WATER is based on the conceptual metaphor AN OBJECT OF INANIMATE NATURE - IS A HUMAN 
BEING ( $\nabla$ WATER - IS A WOMAN). Here the author shows the sea as a woman who seduces a man, calls him with a tender voice, invites him into her depth, tries to separate a husband from his wife. The man is obsessed with the sea, refuses to leave the shore, and sends his wife to buy him different trifles because he wants to be with the sea alone. The sea "uses" the man and with the large wave sends his drowned body back to the coast, to his wife. The sea does not need it any more. She is alluring other naïve males, her potential victims.

In "The lake", concept-element of WATER is described simultaneously as power that is able to charm a human (magician) and power that can kill humans: $\nabla$ WATER - IS A MAGICIAN, able to melt and dissolve part of the body (Water is like a magician. Sawing you in half. It feels as if you were cut in two, part of you, the lower part, sugar, melting, dissolving away. Cool water, and once in a while a very elegantly stumbling wave that fell with a flourish of lace); $\nabla$ WATER - IS A MURDERER and $\nabla$ WATER - IS DEATH (I thought of Tally, swimming out into the water last May, with her pigtails trailing, blond. She went laughing, and the sun was on her small twelve-year-old shoulders. I thought of the water settling quiet, of the life guard leaping into it, of Tally's mother screaming, and of how Tally never came out. ...She had gone too far out, and the lake would not let her return).

This dualistic image of WATER corresponds to the meaning of WATER as a global symbol: two-way positive and negative flow of creation and destruction (Cirlot 2001). The image of WATER as an abstract phenomenon is represented in "The day it rained before" - the main characters, who have been waiting for the rain, finally got it, but not as real water, but as the sounds of the harp, played by WOMAN (Miss Hillgood drew a chair under her, rested the golden harp gently back on her shoulder, and put her hands to the strings... And then Miss Hillgood moved her hands... like a little girl putting her hands out of a window to feel what? Why, of course, of course! To feel the rain. The echo of the first shower vanished down remote causeways and roofdrains, away. Miss Hillgood played). The basis of such WATER image is the general 
conceptual scheme AN OBJECT OF INANIMATE NATURE - IS ABSTRACT PHENOMENON, where $\nabla$ WATER (RAIN) - IS MUSIC (She played and it wasn't a tune they knew at all, but it was a tune they had heard a thousand times in their long lives, words or not, melody or not. She played and each time her fingers moved, the rain fell pattering through the dark hotel. The rain fell cool at the open windows and the rain rinsed down the baked floorboards of the porch. The rain fell on the rooftop and fell on hissing sand, it fell on rusted car and empty stable and dead cactus in the yard. It washed the windows and laid the dust and filled the rain-barrels). $\nabla$ WATER (RAIN) - IS THE SOUND OF HARP; the main characters were listening with delight, it felt like falling rain on their faces (The sound of the harp playing, the sound of the cool water falling every night and every night of their lives, after this... Seated there, they felt their heads tilt slowly back to let the rain fall where it would); $\nabla$ WATER (RAIN) - IS ARTEFACT (HARP) (The harp, the harp. Listen, listen! The fifty years of drought were over. The time of the long rains had come).

In a broader sense, we can say that the woman who played the harp, evoking in such a way the image of the rain in the minds of the main characters, turns into this image and becomes the embodiment of WATER. The basis of such metaphorical interpretation of the WATER concept is conceptual metaphor A HUMAN BEING - IS AN OBJECT OF INANIMATE NATURE (A WOMAN - IS $\nabla$ WATER).

Hence, the WATER concept has many different positive and negative images, represented in the figure below (see Fig. 4). 


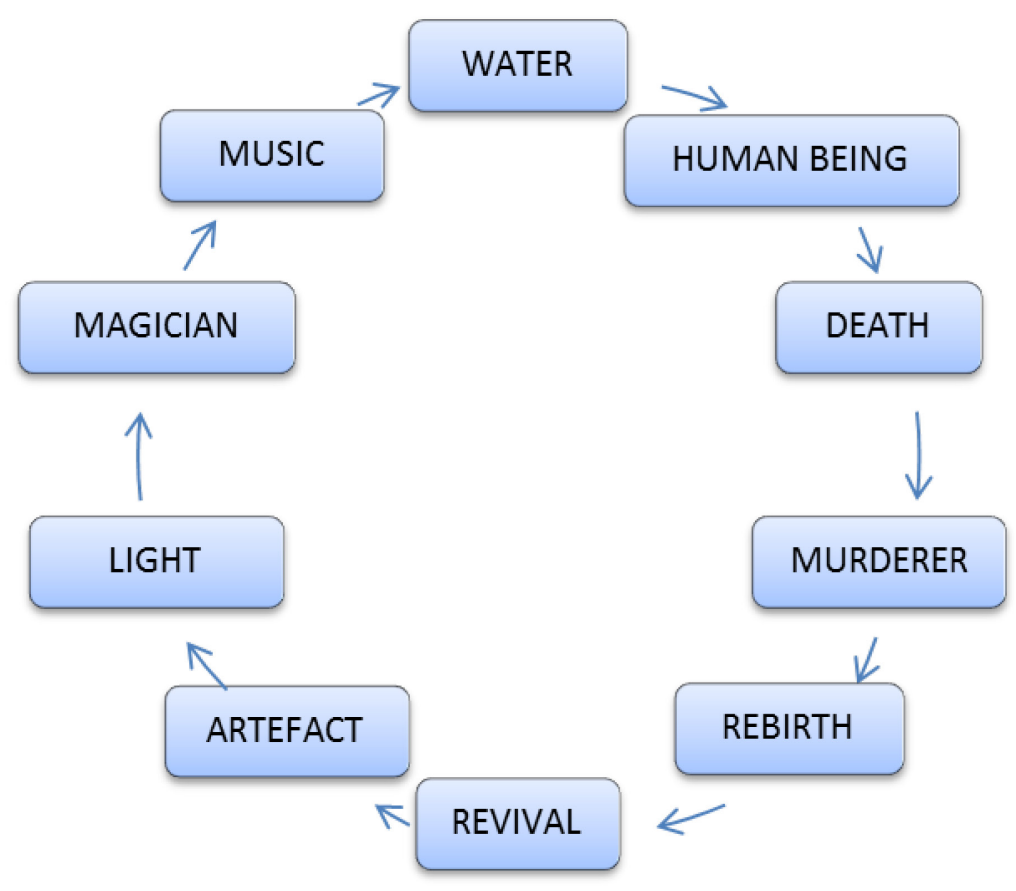

Figure 4. The image-bearing component of the WATER concept

For Fig. 2 and 4 we have chosen different graphs, because we want once again to accentuate that fire can be the source of explosion, death, hope, etc. Presenting imagebearing component of the WATER concept like a circle reminds us about hydrological water cycle, whereas fire is being put into the centre of the graph.

The most commonly used images (see Fig. 5) that reflect the embodiment of the WATER concept are being personified and acquire features of HUMAN BEINGS (4 cases), both men and women or get image-metaphorical embodiment of DEATH (4 cases), MURDERER ( 2 cases), ARTEFACT ( 3 cases), and ABSTRACT PHENOMENON (2 cases). 


\section{WATER}

\section{HUMAN BEING}

\section{DEATH and MURDERER}

ABSTRACT

PHENOMENON

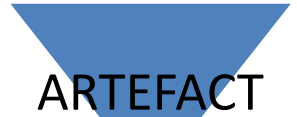

Figure 5. The most common images of the water concept

Figures 3 and 5 also have different graphs: they reflect the way alchemists depicted fire as a triangle $\Delta$ and water as a triangle with an inverted apex $\nabla$.

The sense-bearing components of the WATER concept are such lexical units as regeneration, rebirth, death, destruction and enlightenment. Reverse conceptual scheme, where the WATER concept is source domain is also presented in the analyzed examples. Considering the conceptual structure $\nabla$ WATER - IS A HUMAN BEING, we can observe that, mostly, target domain WATER gets metaphorical embodiment of WOMAN, which is directly connected with the symbol of Yin that represents it.

\section{The combination of the literary concepts FIRE and WATER embodied in Bradbury's (science) fiction}

Above we have presented the results, showing great potential of FIRE and WATER as inseparable elements in Bradbury's works, which penetrate into each other and unite, symbolizing the contradictions of the material world. Thus, we have concluded that it will be interesting to analyze them not as two separate concepts, but as combined elements, which complement as well as contradict each other, exactly like Yin and 
Yang. We have chosen for our analysis four stories that unite these two concepts and represent Yin (female) and Yang (male) elements simultaneously. These are such stories, as "August 2026: there will be soft rains", "The golden kite, the silver wind", "Frost and fire" and "The long rain". It should be noted that even the titles of these four stories show the connection between the concept-elements they represent: "August 2026: there will be soft rains" and "The long rain" have in their titles the lexeme rain, which may indicate that the images of WATER will prevail in these stories rather than the images of FIRE, and vice versa. We guess that in "The golden kite, the silver wind" and "Frost and fire", the titles of which include lexemes golden and fire, as well as frost, metaphorical images will be more associated with fire than with water. Let us verify this assumption.

The first story "August 2026: there will come soft rains" shows the struggle between FIRE and WATER. This story is futuristic: events take place in the distant year 2026 in an abandoned house; people do not live in it, because there are no humans on the Earth any more. All housework is done by robots - the mechanical mice clean the house, the cooker prepares food and bath waters itself (At eight-thirty the eggs were shriveled and the toast was like stone. An aluminium wedge scraped them into the sink, where hot water whirled them down a metal throat which digested and flushed them away to the distant sea. The dirty dishes were dropped into a hot washer and emerged twinkling dry...Out of warrens in the wall, tiny robot mice darted. The rooms were a crawl with the small cleaning animals, all rubber and metal...Five o'clock. The bath filled with clear hot water.). Suddenly fire starts in the house; the house tries to survive: mechanical mice spray water, trying to put out the fire, but the quenching rain cannot overcome FIRE ("Fire, fire, fire!" The house tried to save itself. Doors sprang tightly shut, but the windows were broken by the heat and the wind blew and sucked upon the fire...While scurrying water rats squeaked from the walls, pistoled their water, and ran for more. And the wall sprays let down showers of mechanical rain...But too late. Somewhere, sighing, a pump shrugged to a stop. The quenching rain ceased). 
Both concepts are represented in this story as human beings: WATER fights and FIRE devours objects, jumps on the window, repaints porter and lies in bed (The fire crackled up the stairs. It fed upon Picassos and Matisses in the upper halls, like delicacies, baking off the oily flesh, tenderly crisping the canvases into black shavings. Now the fire lay in beds, stood in windows, changed the colors of drapes!). Such metaphorical thinking is based on the conceptual metaphor AN OBJECT OF INANIMATE NATURE - IS A HUMAN BEING ( $\triangle$ FIRE - IS A HUMAN BEING; $\nabla$ WATER - IS A HUMAN BEING). At the end of this story FIRE finally wins - the house explodes (The fire burst the house and let it slam flat down, puffing out skirts of spark and smoke). Bradbury endowed with human qualities not only the elements of FIRE and WATER that were struggling with each other, but all other artefacts in the house - they were alive and did some work. Such an interpretation of metaphorical images leads us to the following conceptual metaphor AN ARTEFACT - IS A HUMAN BEING. Because of the fact that FIRE is essentially opponent to WATER and house, and WATER is traditionally the enemy of FIRE, we can speak about more specific metaphors than $\triangle$ FIRE - IS A HUMAN BEING and $\nabla$ WATER - IS A HUMAN BEING; we can think of FIRE and WATER as AN ADVESARY ( $\triangle$ FIRE IS AN ADVESARY and $\nabla$ WATER - IS AN ADVESARY), the same way Lakoff considered INFLATION (2003: 34).

In "The golden kite, the silver wind", the inhabitants of feudal cities built alternately city walls in the form of different subjects. Initially, inhabitants built their first city wall in the form of big bonfire, but the inhabitants of another city built a city wall in a form of glittering lake, aiming to extinguish fire of nearby city (They have built their city's walls like a great bonfire to bum our stick! "Tell my stone-masons, ... to build our walls in the shape of a shining lake." "And with this lake of water," said the whisper and the old man, "we will quench the fire and put it out forever!"). This continued endlessly; city walls were built as a lightning in return to the city walls as a shield (they have worked all night and shaped their walls like lightning) and as the sun in return to rival's city wall in a form of the moon. These images are not only contrasted to each 
other (sun/moon, fire/water, lightning/ shield), but also complement each other. The city walls represent the city as a part of a metonymic structure - part -whole (wall city). Thus, the city appears in the form of FIRE (lightning, sun), or WATER that is based on the conceptual scheme LOCATION - IS AN OBJECT OF INANIMATE NATURE (CITY - IS $\triangle$ FIRE, CITY - IS $\nabla$ WATER). In this case, FIRE and WATER belong to the source domains - that generate an image of the city. Bradbury once again represents FIRE and WATER as two hostile, but inseparable elements, which is the characteristic feature of their symbolism.

In our opinion, "Frost and fire" is one of the most interesting stories of Bradbury. The title indicates the combination of two elements of nature: FIRE and WATER. This symbolic image-content of natural forces, which rule on the planet and which are rendered by Bradbury in the titles, is extremely important for the holistic perception of the author's conception. Elements of FIRE and WATER (frost in the solid state) also reflect the relationship of life and death, so that these symbols can be interpreted in two ways: fire warms and at the same time burns; melting ice turns into water which is vital to human, but long impact of severe cold is able to take away life (Шлионская, s.a). The main characters of this story can live only eight days because the planet, on which they live, is practically unsuitable for life. The sun brings death to all the plants on this planet and because of its radiation people quickly grow old (This was a planet next to the sun. The nights burned with cold, the days were like torches of fire. It was a violent, impossible world. The people lived in the cliffs to escape the incredible ice and the day of flame... Solar radiations drenched them. Their pulses quickened, two hundred, five hundred, a thousand beats a minute. Their skins thickened, their blood changed. Old age came rushing.). Only at the dawn and sunset, people can get out of their caves, but still it is dangerous, because every morning there is stone rain that kills people (Only at dawn and sunset was the air breath-sweet, flower-strong, and then the cave peoples brought their children out into a stony, barren valley...From far out, Sim heard a rumble of rock, a scream, a silence. Avalanches fell into valley... Every morning at least one person was caught in the downpour). 
So the sun and the rain, which led to the death of people, can be reconstructed in such schemes as $\triangle$ FIRE - IS DEATH, $\triangle$ FIRE - IS A MURDERER and $\nabla$ WATER - IS DEATH, $\nabla$ WATER - IS A MURDERER. Such an image of the sun-killer is shown throughout the whole story. The sun tests the main protagonist - Sim, devouring his body and kills his opponent ("The test of the sun." And this was the worst part of the fight... Sim laughed drunkenly and watched the sweat gather on his dead hands, hesitate, drop off, plunge down toward sand and turn to steam halfway there. Nhoj fell). In fact, the sun is a rival of two men who fought for their right to live; this actualizes such conceptual metaphor as $\triangle$ FIRE - IS AN ADVESARY. After the battle with the Sun and its rival, Sim sees a mirage - blue lake and blue river, in which he falls (All across the valley the winds sang and moaned and Sim saw a blue lake with a blue river feeding it and low white houses near the river with people going and coming in the houses and among the tall green trees. Trees taller than seven men, beside the river mirage). So, WATER is a symbol of victory and hope for the new life, given to the main character by the death of his opponent. At the end of the story the main character with his girlfriend - Lyte - gets to the ship, which can help people live longer than eight days. The ship has a beam of light, through which the protagonist goes back to his tribe, not being frozen at night (The night was cold as death. The heat ray from the ship sliced across the valley, humming, solid and warm. He moved next to it, very close). In this fragment, FIRE for the first time has a positive connotation: it is like a ray of light that gives the hero and others hope and salvation, so we can reconstruct such structures as $\Delta$ FIRE - IS SALVATION and $\triangle$ FIRE - IS HOPE. When people finally were rescued by the ship, a girlfriend of the main protagonist recalls life on both hot and cold planet as a dream ("I had a dream," she said, looking off at something far away. "I dreamed I lived in caves in a cliff on a cold-hot planet where people grew old and died in eight days"). The combination of lexemes cold-hot shows us again the unity of two different elements. It must be mentioned that Lyte, as the name of the protagonist's girlfriend, is also a symbolic name, connected with FIRE; she also has appearance of FIRE (Her eyes were like tiny silver medals, her throat 
curved like the arm of a child. Her hair was blue fire eating at her scalp), so that we can say that she may be the personification of FIRE; that actualizes the conceptual metaphor A HUMAN BEING - IS AN OBJECT OF INANIMATE NATURE (WOMAN - IS $\triangle$ FIRE). In addition, being always close to the main character, even in the worst situations, she gave him hope, power and inspired him. Lyte may also be considered as the homonym of light.

Various images of the FIRE and WATER concepts are represented in "The long rain". According to the plot of this story, men seek Sunny Dome on Venus, to hide there from the rain, as the rain was going on constantly on this planet ("It never stops raining on Venus. It just goes on and on. I've lived here for ten years and I never saw a minute, or even a second, when it wasn't pouring") At the beginning of the story Bradbury depicts RAIN as A HUMAN BEING, capable of cutting trees and bushes and wrinkled hands of people (It was a hard rain, a perpetual rain, a sweating and steaming rain; it was a mizzle, a downpour, a fountain, a whipping at the eyes, an undertow at the ankles; it was a rain todrown all rains and the memory of rains. It came by the pound and the ton, it hacked at the jungle and cut the trees like scissors and shaved the grass and tunneled the soil and molted the bushes. It shrank men's hands into the hands of wrinkled apes; it rained a solid glassy rain, and it never stopped); in the middle of the story RAIN dances on the skin and clothes of the main heroes (The rain danced on their skin, on their wet uniforms). All these images are based on conceptual metaphor $\nabla$ WATER (RAIN) - IS A HUMAN BEING.

Men felt very tired of the constant rain; their psychological and physical condition was degrading (Who can sleep with rain slamming their head, banging away. I'd give anything for a hat. Anything at all, just so it wouldn't hit my head any more. I get headaches. My head is sore; it hurts all the time."...You can't sleep, you can't breathe right, and you're crazy from just being soggy). Endless rain that makes the protagonists ill builds the images of WATER as ILLNESS, PAIN and INSANITY: $\nabla$ WATER - IS ILLNESS, $\nabla$ WATER - IS PAIN and $\nabla$ WATER - IS INSANITY. 
Moreover, the rain causes the death of one of the main characters ("Pickard!" The man would not reply. He simply stood there for a long while with the bubbles of rain...He'll just stand here with his head up and let the rain come in his nostrils and his mouth. He'll breathe the water"). In this excerpt, concept of WATER and its lexeme - rain actualizes such conceptual metaphor as $\nabla$ WATER - IS DEATH.

It is noteworthy that the FIRE concept that is also realized in this story is identified by the lexeme Sun Dome, which was looked for by the main protagonists to warm up and dry from the endless water; and in the form of Electrical Storm, that threw lightning and even managed to kill one of the protagonists. In the center of the Sun Dome there was the sun, depicted as a yellow ball of fire (in the center of the Sun Dome, of course, was a sun. A small floating free globe of yellow fire), so the basis of this image is a conceptual metaphor SUN - IS $\triangle$ FIRE; the image of the electrical storm that brought death is represented by such conceptual metaphors as $\triangle$ FIRE - IS A MURDERER and $\triangle$ FIRE - IS DEATH.

Thus, having considered the stories where the FIRE and WATER concepts are represented in unison, we noted that FIRE and WATER act mostly as A HUMAN and as DESTRUCTIVE FORCE that brings death. In addition to these images, the FIRE concept has the image of ADVESARY and MURDERER, and the WATER concept has the following additional images as ILLNESS, PAIN and INSANITY. These basic images we present in the figure below (See Fig. 6). 


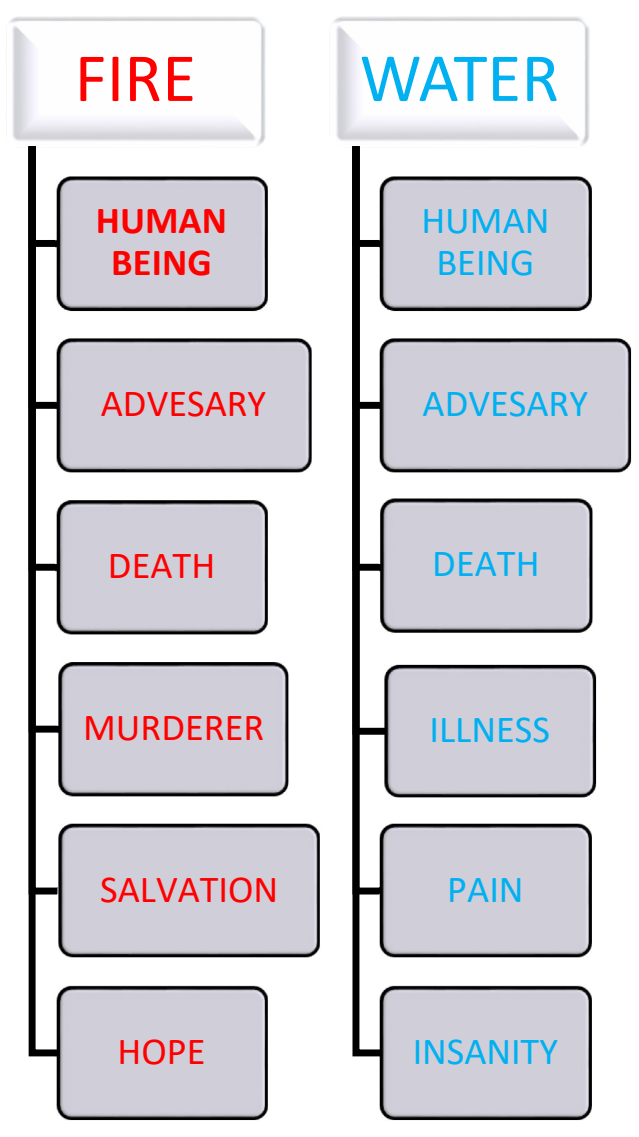

Figure 6. The main metaphoric images of the FIRE and WATER concepts

The most common source domains to the target domains FIRE and WATER are the HUMAN BEINGS (twice for water and once for fire), DEATH (twice for both concepts) and MURDERER (twice for fire). It is clearly seen in the figure above that in the stories where embodied concept-elements FIRE and WATER are combined, both of these concepts have the same number of metaphorical images that indicate their correlation and contradistinction in Bradbury's works. It has been also investigated that the FIRE and WATER concepts were equally revealed in the short stories, which titles were connected with these concepts; it proofs again the unity of these concepts.

\section{Psycholinguistic analysis of Bradbury's (science) fiction}

Now we would like to analyse Bradbury's works using the methodology of Belyanin that concentrates on identifying the typology of psycholinguistic texts (Белянин 2000). This is approach to the analysis of literary texts, based on the detection of emotional and semantic dominant, i.e. a literary text is described through the worldview it reflects 
(Белянин 2000: 54). The author claims that there are seven basic types of the literary text: light, active, dark, sad, merry, beautiful and complex (Белянин 2000: 75). We would like to relate the FIRE and WATER concepts embodied in Bradbury's works to this classification, but firstly let us have a brief look at the main types of texts, suggested by Belyanin.

The first type - light text - depicts nature, religion (especially Zen Buddhism) and shows the actual problems of society, history and culture. These texts may present the following two postulates: "All life is unique, inimitable and self-sufficient" and "I know the truth and show my understanding of life to others" (Белянин 2000: 89). The basis of the light texts' worldview is the description of the individual's world and the natural world that surrounds the individuals. Lexical units used in light texts are grouped around the meaning of "unique" and "inimitable"; it can be such epithets as "honest", "direct", "true", "pure", "bright", "sonorous", "transparent", "incomparable" and others. As for the death of the main protagonists: it often happens to the main protagonist in the light texts, but it is not clearly represented - it seems that there is no death, because life is presented as infinite and eternal within this worldview (Белянин 2000: 94).

Active texts depict the struggle of a positive character and his supporters with the feudal forces. An active text style is energetic, dynamic and sometimes sharp. Protagonists of active texts try to realize their ideas, which in their opinion are valuable and important to the society. The main protagonist organizes around himself his supporters, friends and advisers who believe in his idea, apathy and honesty. In active texts, there are two possible endings - a victory of good over evil or disclosure of enemies and betrayers. In accordance with the emotional and semantic dominant of active texts, happiness means to serve the idea in the struggle for happiness. Past events in active texts are alternations of light and dark periods, present events are struggle and future is light and fair (Белянин 2000: 101). So, lexical units, representing active texts, are struggle, noble idea, conflict and ideals. 
As far as the dark texts are the most frequent group of texts, Belyanin pays much attention to them. In the dark texts, there is a tough fight between good and evil. Life is hard and nasty, enemies are clever and dangerous, and human is a toy in the hands of hostile forces. Dark texts have several types (e.g., dark texts themselves, simple, violent) and they are characterized by such semantic categories, as large, small (the character's size), deal, fading, bottom, water, moon, twilight, and smell (unpleasant). Heroes of such texts are representatives of dangerous professions: sailors, soldiers, border guards, operating in harsh conditions - in the woods, at sea, in a spaceship, in the north. Thus, dark texts describe the actions of the ordinary man in difficult conditions (Белянин 2000: 112). Dark texts belong to such genres as social and political journalism, detectives, science fiction, stories about animals and fairy tales for children. Characters of dark texts can be of four types: simple character, dangerous wise head, intermediate and double character. The image system of dark texts is extremely rich; it is represented by such emotional states, as depression, mood changes, laughing (the main character does not like being laughed at), automatisms (repeating descriptions of actions). Other features of the dark texts are spatial sensations like water and the process of falling down; the latter is quite often done into the water, sea, lake or river. In the dark texts it often rains, sometimes water can be in the titles of works (Белянин 2000: 145). Visual sensations include twilight, moon and fire. As we can see from the information presented above, the author of this method regards texts that include the FIRE and WATER concepts as those, which belong to the group of the dark texts.

Another type of texts is sad texts; the basic idea of them is to cherish every passing day and love life, despite the fact that it can be difficult. Heroes of such texts are young people, full of hope, though they die, or the old and the poor who recall their beautiful youth. Past is beautiful but with errors; that is why there are suffering and guilt in the present and in the future there will be loneliness, old age and death. The structure of emotional and semantic dominant of sad texts consists of such key semantic 
complexes, as age (youth/joy), life/death, difficulty, breath and smells (pleasant). Sad texts are characterized by such features as fatalism, isolation, poverty, cold, etc.

Merry texts show a successful hero, who is always optimistic, witty and erudite; he/she has courageous profession - a parachutist, a driver, a traveler, a cop, a musician. Merry text begins with the fact that the protagonist must act boldly, then he/she gets into adventures and at the end of the text he/she overcomes all opponents and is still seeking new adventures (Белянин 2000: 195). The peculiarities of such types of the text are physical strength (strong and healthy character), flight, singing, sociability, appetite, erudition, etc.

The next type of the text is a beautiful one; these texts show a woman who is suffering and experiencing a difficult situation. Beautiful texts are close to merry texts, because both types have usually a large number of heroes, but in merry texts, the hero is always successful, whereas in beautiful texts the hero is mostly suffering and humiliated. The characteristics of beautiful texts are social state, family secrets, appearance, emotion, body, money, etc. (Белянин 2000: 217).

The last type of this classification is complex texts (Белянин 2000: 242). These texts are probably the second complicated type of the text after the dark ones. Complex texts are mostly often found in science fiction. The action in complex texts usually takes place in two worlds - the real and the fictional, and it can be transition between them. The fictional world is usually more complicated than real: text can depict robots, highspeed machines; events that may occur in underground cities. Time is also difficult in complex texts; it may stop, go faster or slow down. Many of Bradbury's texts belong to this group, but not all of them have the FIRE and WATER concepts in them.

Belyanin claims that there are also mixed texts (for example, light and sad or active and dark), just as there are different types of human temperament; but there are no virtually pure text types as well as the types of temperament (Белянин 2000: 266). 
We would like to stress once again that Bradbury's works are so diverse and original that in his works we may find absolutely all text types. He successfully portrays nature and speaks about religion (light texts), his characters struggle with the principal elements (dark texts); they fight for their ideals (active texts) in unusual places (beautiful texts), travel and seek adventure (merry texts) and remember their youth (sad texts). But Bradbury is considered to be a science fiction writer; so we can say that his works are mostly complex and dark texts.

Using this theory, we refer texts including the FIRE and WATER concepts to the dark ones. The proof of this idea is that Bradbury often uses in the title of the story the lexeme, which correlates with FIRE ("The great fire", "Pillar of fire", "Touched with fire", "Fire balloons", etc.) and WATER ("The lake", "The day it rained before", "And the sailor, home from the sea", "The long rain", "Yes, we'll gather at the river", etc.). Another feature is that his characters often fall into the water (e.g., in the well in "The one who waits" or river in "Frost and fire") or are at the sea ("And the sailor, home from the sea", "The shoreline at sunset"," The fog horn", "The women", "The Picasso summer"). Futuristic stories demonstrate not only the dark, but also complex structure of these texts: the adventures of the main characters take place in space and/or in a spaceship (e.g., "The million-year picnic", "Kaleidoscope", "The golden apples of the sun", "The gift" and others), on distant planet Mars ("The exiles", "Fire balloons", "The concrete mixer", "Dark they were, and golden eyed (the naming of names)", "The strawberry window" and others) and on rainy Venus ("All summer in a day", "The long rain").

Many stories by Bradbury are dedicated to machines (complex texts, e.g., "The happiness machine", "Forever and the earth", etc.) and human's fight or elements' fight with these machines (complex and dark texts, e.g., "August 2026: there will come soft rains", "Marionettes, Inc.", "The city", etc.). Considering the fact that Bradbury often describes the nature and human as unique individuals, we can argue that a great number of light texts are also presented in his works. 
However, it is possible to assume that Bradbury's works are not purely dark, light or complex in their structure, as Bradbury combines different techniques to describe the events in his works, and the characters he uses are very diverse - from a little boy in "The lake" to the old great-grandmother in "The leave-taking". Since, the author of this methodology claims that there are no pure types of the text and the presented typology of the literary texts is believed to be fundamentally open (Белянин 2000: 266).

When we applied the methodology worked out by Belyanin we guessed that it is possible to connect his very interesting classification of texts with FIRE and WATER as objects of our research. Now we may state that this method of text analysis is not connected directly with FIRE and WATER; it is connected mainly with the topics of Bradbury's works. Classifying his (science) fiction like dark, active and other texts gives us possibility to penetrate deeper into the worlds of this outstanding writer and to decode more pieces of information hidden by him in the in the depths of his wonderful texts.

\section{Discussion and conclusions}

Bradbury's works are so considerable and multifaceted that in order to describe all the concepts of his works, we would need to write a thesis, not a full-length article. Our article is but a small part of research into his vast collections of stories and the embodied concept-elements FIRE and WATER are only a part of the large megaconcept NATURE, which is represented in Bradbury's works. We have thoroughly analyzed the literary FIRE and WATER concepts, using one of the most common research methodologies for the study of the concepts, presented in the works of many scholars. According to this methodology, concept, as a complex structured system, has three basic components: notional, image- and sense-bearing. Due to the componential and definitional analysis of lexemes indicating the FIRE and WATER concepts, as well as due to the strategy of conceptual analysis, in terms of conceptual metaphors, we have investigated the main images embodied in these concepts. 
The results of our research are thus presented in two summary tables, which vividly show how FIRE and WATER are presented in our language material.

Table 1. Correlation between most typical symbol meanings and the WATER concept components in Bradbury's (science) fiction

\begin{tabular}{|l|l|l|}
\hline \multicolumn{1}{|c|}{$\begin{array}{c}\text { Water symbol } \\
\text { meanings }\end{array}$} & \multicolumn{1}{|c|}{$\begin{array}{c}\text { Image-bearing } \\
\text { component }\end{array}$} & \multicolumn{1}{c|}{$\begin{array}{c}\text { Sense-bearing } \\
\text { component }\end{array}$} \\
\hline clarification & Water is Rebirth & regeneration \\
\hline $\begin{array}{l}\text { temptation and sexual } \\
\text { passion }\end{array}$ & $\begin{array}{l}\text { Water is a Woman who } \\
\text { seduces men }\end{array}$ & desire \\
\hline $\begin{array}{l}\text { mediator between life } \\
\text { and death }\end{array}$ & $\begin{array}{l}\text { Water is Death, which } \\
\text { destroys }\end{array}$ & eternity \\
\hline destructive force & $\begin{array}{l}\text { Water is a Man who is a } \\
\text { murderer }\end{array}$ & death \\
\hline $\begin{array}{l}\text { two-way positive and } \\
\text { negative flow of } \\
\text { creation and destruction }\end{array}$ & Water is Revival & renaissance \\
\hline $\begin{array}{l}\text { two-way positive and } \\
\text { negative flow of } \\
\text { creation and destruction }\end{array}$ & Water is Destruction & degeneration \\
\hline wisdom & Water is Light & enlightenment \\
\hline spiritual life & Water is Magician & enchantment \\
\hline $\begin{array}{l}\text { invisible energy of } \\
\text { transformation }\end{array}$ & Water is Music & appeasement \\
\hline $\begin{array}{l}\text { triumph of the apparent } \\
\text { weakness over the force }\end{array}$ & Water is Adversary & resistance \\
\hline
\end{tabular}

Table 2. Correlation between most typical symbol meanings and the FIRE concept components in Bradbury's (science) fiction

\begin{tabular}{|l|l|l|}
\hline \multicolumn{1}{|c|}{$\begin{array}{c}\text { Fire symbol } \\
\text { meanings }\end{array}$} & \multicolumn{1}{c|}{$\begin{array}{c}\text { Image-bearing } \\
\text { component }\end{array}$} & \multicolumn{1}{|c|}{$\begin{array}{c}\text { Sense-bearing } \\
\text { component } \\
\text { regeneration }\end{array}$} \\
\hline clarification & Fire is Rebirth & death \\
\hline destructive force & $\begin{array}{l}\text { Fire is Man who is a } \\
\text { murderer }\end{array}$ & demolition \\
\hline living creature that eats & Fire is a Devourer & faith \\
\hline divine energy & Fire is a Gift from God & superiority \\
\hline ambition & Fire is an Animal (Lion) & conflagration \\
\hline destructive energy & Fire is Explosion & eternity \\
\hline $\begin{array}{l}\text { mediator between forms, } \\
\text { which vanish and appear } \\
\text { (transformation) }\end{array}$ & Fire is Death & \\
\hline
\end{tabular}




\begin{tabular}{|l|l|l|}
\hline $\begin{array}{l}\text { threatening force of } \\
\text { nature }\end{array}$ & Fire is a Destroyer & degeneration \\
\hline creative force & Fire is Revival & renaissance \\
\hline $\begin{array}{l}\text { a symbol of revenge or } \\
\text { protection from evil }\end{array}$ & Fire is Adversary & resistance \\
\hline revelation & $\begin{array}{l}\text { Fire is Hope and } \\
\text { Salvation }\end{array}$ & renewal \\
\hline
\end{tabular}

Now let us make some comments on the tables presented above. As the FIRE and WATER concepts make up two of the four base elements, we have examined their universal symbolism in general and in particular, using as an example Bradbury's (science) fiction. Our research has shown that the FIRE concept as a symbol has such positive meanings, as clarification, revival, hope, transformation, and rebirth; among the negative meanings are images of destruction, murder, death, devourer and adversary. The WATER symbol has such positive signs as clarification, renewal, rebirth and light, and such negative signs as destruction, death, rivalry, insanity and pain. Our research has confirmed the fact that both concept-symbols are dualistic in nature, antithetical and inseparable: in Bradbury's works, these concepts simultaneously penetrate into each other, symbolizing the contradictions of the material world.

In our research, we have combined the method of conceptual analysis with the fundamentals of Chinese philosophy of life: we have explored how FIRE and WATER, which are respectively the symbols of Yin and Yang, manifested in the works of Bradbury. The results have shown that FIRE and WATER as basic concept-elements in Bradbury's works, have a male or female component. Such personification is a part of the conceptual structure GREAT CHAIN OF BEING. Thus, the concept-element FIRE is basically personalized and acquires male features ( $\triangle$ FIRE - IS A MAN); the concept-element WATER is also personalized and acquires female features ( $\nabla$ WATER - IS A WOMAN). So, we suppose that Bradbury implicitly uses Chinese philosophy of life in his works. 
In addition to personalized images the target of the FIRE concept is presented in positive images of ARTEFACTS (cup, dome), as an ABSTRACT PHENOMENON (hope, rebirth) and ANIMAL; and in negative images such as EXPLOSION, DEATH, MURDERER, DESTROER and DEVOURER. In turn, target the WATER concept is represented in such positive images as an ARTEFACT (harp), ABSTRACT PHENOMENON (music, light, rebirth); negative images are DEATH, DESTRUCTION, PAIN, MURDERER and INSANITY. Having examined those short stories where there is a combination of the FIRE and WATER concepts, we discovered the same number of metaphorical images of these concepts, which undoubtedly indicate their interconnection and opposition in Bradbury's (science) fiction.

It is worth noting that we have explored not only the scope, but also the range of those conceptual structures that represent the FIRE and WATER concepts. It has been demonstrated that these concepts can also be source concepts to target concept A HUMAN and ABSTRACT PHENOMENON; these images are inverse images of the conceptual structure GREAT CHAIN OF BEING.

Consequently, the most commonly used metaphoric images are personalized conceptual structures $\triangle$ FIRE - IS A HUMAN BEING and A HUMAN BEING - IS $\triangle$ FIRE; $\nabla$ WATER - IS A HUMAN BEING and A HUMAN BEING - IS $\nabla$ WATER.

Having used the method of psycholinguistic typology of the literary text, based on the detection of emotional and semantic dominants in fiction, we have discovered that Bradbury's works are represented by different typology of texts. In our opinion, his works mostly belong to the dark and complex types of the texts, to the structure of which we also attribute the FIRE and WATER concepts, as the most frequently embodied concepts in Bradbury's (science) fiction.

Further research connected with these or any other concepts embodied in Bradbury's (science) fiction would have great potential. 


\section{References}

Arutiunova, N.D. / Арутюнова Н.Д. (1990). Образ, метафора, символ в контексте жизни и культуры. In Res Philologica: Филологические исследования памяти академика Г.В. Степанова. Д.С. Лихачев (отв. ред.). Москва-Ленинград: Наука, c. 71-88.

Askoldov, S.A. / Аскольдов С.А. (1997). Концепт и слово. In Русская словесность. От теории словесности к структуре текста: Антология. Москва: Academia, с. 267-279.

Averintsev, S.S. / Аверинцев С.С. (1999). София-Логос: Словарь. Available at: http://azbyka.ru/otechnik/Sergej_Averincev/sofija-logos-slovar/

Belekhova, L.I. / Белехова Л.И. (2013). Концепт ЖИЗНЬ в американской поэзии In Лингвоконщептология: перспективные направления: монография / под. ред. А.Э. Левицкого, С.И. Потапенко, И.В. Недайновой. Луганск: Изд-во ГУ "ЛНУ имени Тараса Шевченко", с. 239-257.

Belyanin, V.P. / Белянин В.П. (2000). Основы психолингвистической диагностики (Модели мира в литературе). Москва: Тривола.

Beznisko, N.A. / Безниско Н.A. (2003). Своебразие концепщии гуманизма в рассказах Рэя Брэдбери и Антона Павловича Чехова. Available at: http://www.bradbury.org.ru/tip-op-aaa-252/

Bierwiaczonek, B. (2002). A cognitive study of the concept of LOVE in English. Katowice: Wydawnictwo Universytetu Śląskiego.

Biography and creative activity of Ray Bradbury / Биография и творческая деятельность Рэя Дугласа Брэдбери. Available at: http://real-books.ru/ zarubezhnye-pisateli/rehji-brehdberi/biografiya-rehya-brehdberi.html

Bishop, C.M. (2007). Neural networks for pattern and concept recognition. Oxford: Oxford University Press.

Boldyrev, N.N. / Болдырев Н. Н. (2000). Когнитивная семантика: Курс лекиий по английской филологии. Тамбов: Издательство Тамбовского университета. 
Bolotova, N.S. / Болотова Н.C. (2007). О методике изучения ассоциативного слоя художественного концепта в тексте. In Вестник ТГПУ, Серия: ГУМАНИТАРНЫЕ НАУКИ (ФИЛОЛОГИЯ), 2(65), с. 74-79.

Bondarenko, O.S. / Бондаренко О.С. (2005). Концепти "ЧОЛОВІК" та "ЖІНКА" в украӥнській та англійській мовних картинах світу: Автореф. дис. ... канд. філол. наук. Донецьк: Донецький національний університет.

Bradbury, R. (2003). Bradbury Stories: 100 of his most celebrated tales. New York: HarpersCollins Publishers.

Bradbury, R. (2005). A sound of thunder and other stories. New York: HarpersCollins Publishers.

Bradbury, R. (2013). Fahrenheit 451: A Novel. New York: Simon \& Schuster Paperbacks.

Bucharov, P. (1970). Concept of knowledge. Evanston: Northwestern University Press. Butyakov, L. / Бутяков Л. (2000). Марсианин из Лос-Анджелеса. Вступительная статья. In Здесь могут водиться тигры:: Рассказы. СПб.: Азбука, с. 5-12.

Cambridge Learner's Dictionary. Available at:

http://dictionary.cambridge.org/ru/словарь/английский-для-учащихся/

Cirlot, J.E. (2001). A dictionary of symbols. London: Routledge.

Conceptual linguistics: Perspective tendencies: monograph. (2013). Levitsky, A.E., Potapenko, S.I., Nedaynova, I.V. (eds.). / Лингвоконцептология: перспективные направления: монография / под. ред. А.Э. Левицкого, С.И. Потапенко, И.В. Недайновой. Луганск: Изд-во ГУ "ЛНУ имени Тараса Шевченко".

Cooper, J. / Купер Дж. (1995). Энщиклопедия символов. Москва: Ассоциация Духовного Единения "Золотой Век".

Davydyuk, Yu. (2014). Linguistic verbalization of basic literary concepts in the short stories by O.Henry. In International Journal of Languages and Literature. New York: American Research Institute for Policy Development, 2(1), p. 285-305. Available at: http://aripd.org/journal/index/ijll/vol-2-no-1-march-2014-current-issue-ijll/

Eco, U. (1986). Semiotics and the philosophy of language. Bloomington: Indiana University Press. 
Fauconnier, J. \& Turner, M. (1998). Principles of conceptual integration In Discourse and cognition: Bridging the gap. Koenig, J.R. (ed). Stanford: CSLI Publications, p. 269-283.

Fauconnier, J. \& Turner, M. (2002). The way we think: Conceptual blending and the mind's hidden complexities. N.Y.: Basic Books.

Ferber, M. (1999). A Dictionary of Literary Symbols. Cambridge: Cambridge University Press.

Fodor, J.A. (1998). Concepts. Where cognitive went wrong. Oxford: Clarendon Press. Ford, J. (2012). In a passing meditation on Ray Bradbury's religion. Available at: http://www.patheos.com/blogs/monkeymind/2012/08/a-passing-meditation-on-raybradburys-religion.html

Greif, P. Peter Greif's symbolarium. Краткая энциклопедия символов. Available at: http://www.symbolarium.ru/index.php/Краткая_энциклопедия_символов

Gritsanov, А. / Грицанов А. История философии. Энциклопедия. Available at: http://www.gumer.info/bogoslov_Buks/Philos/Grican/_189.php

Gudkov, D.В. / Гудков Д.Б. (2016). Концепт патриот в русском политическом дискурсе (на материале "Новой газеты" и "Завтра") In Язык, сознание, коммуникащия: Сб. статей / Отв. ред. серии В.В. Красных, А.И. Изотов. Москва: МАКС Пресс, 53, p. 68-74.

Guzii, T. (2014). Value component of linguocultural concept GOD in the Old English language. In European Journal of Science and Theology. December, 10(6), p. 99-104. Horobets, I.S. / Горобець I.C. (2007). Мовні засоби відтворення концепту ЗЛОЧИНЕЦЬ у сучасній американській художній прозі та газетній публіиистииі: Автореф. дис. ... канд. філол. наук. Донецьк: Донецький національний університет.

Jackendoff, R. (1992). What is a concept? In Frames, fields, and contrasts. New essays in semantics find lexical organization. Hillsdale: Lawrence Erlbaum Associates, p. 191-209. 
Jackendoff, R. (1999). What is a concept, that a person may grasp it? In Concepts: core readings. Margolis, E. \& Laurence, S. (eds.). Cambridge, Mass.: The MIT Press, p. 305-333.

Izotova, N.P. / Ізотова Н.П. (2009). Текстовий концепт ШЛЯХ ДО СЛАВИ в англомовних біографічних романах XX століття: семантико-когнітивний та наративний аспекти: Автореф. дис ... канд. філол. наук. Київ: Київський національний лінгвістичний університет.

Kaganovska, O.M. / Кагановська О.М. (2002). Текстові конщепти художньої прози (на матеріалі французької романістики середини ХХ сторіччя). Київ: Вид. центр КНЛУ.

Kaganovska, O.M. / Кагановська О.М. (2003). Текстові конщепти художньої прози: когнітивна та комунікативна динаміка (на матеріалі франиузької романістики середини XX сторіччя): автореферат дис. ... канд. філол. наук. Київ: Київський національний лінгвістичний університет.

Karasik, V.I. / Карасик В.И. (2004). Языюквой круг: личность, концепты, дискурс. Волгоград: Перемена.

Karasik, V.I. \& Sternin, J.А. / Карасик В.И., Стернин И.А. (2007). Антология кониептов. Москва: Гнозис.

Kövecses, Z. (1990). Emotion concepts. New York: Springer-Verlag.

Kövecses, Z. (2000). Metaphor and emotion. Language, culture and body in human feeling. Cambridge: Cambridge University Press.

Koubriakova, E.S. et al. / Кубрякова Е.С. и др. (1996). Концепт. In Краткий словарь когнитивных терминов. Москва: МГУ, с. 90-93.

Lakoff, G. \& Johnson, M. (2003). Metaphors we live by. London: The University of Chicago Press.

Lakoff, G. \& Turner, M. (1989). More than cool reason: A field guide to poetic metaphor. London: The University of Chicago Press.

Levitsky, А.Е. / Левицкий А.Э. (2013). Концепты СОН и МЕЧТА в восточнославянских и западногерманских лингвокультурах. In Лингвоконщептология: перспективные направления: монография / под. ред. 
А.Э. Левицкого, С.И. Потапенко, И.В. Недайновой. Луганск: Изд-во ГУ "ЛНУ имени Тараса Шевченко", с. 502-523.

Litvinova, V.V. / Литвинова В.В. (2009). Индивидуально-авторские концепты в структуре художественного мира Рэя Брэдбери: автореф. дис. ... канд. филол. наук. Краснодар: Краснодарский государственный университет.

Longman dictionary of contemporary English. Available at: http://www.ldoceonline.com

Lotman, Yu. М. / Лотман Ю.М. (1996). Внутри мыслящих миров. Человек-текст - семиосфера - история. Москва: Языки русской культуры.

Makarova, A. \& Bochkaryova, N.S. / Макарова А., Бочкарёва Н.C. (2008). Тема технического прогресса в рассказе Р. Брэдбери "Вельд". In Мировая литература в контексте культуры. Сборник статей по материалам Международной научной конференщии, 3. Пермь: Пермский государственный университет, с. 166168.

Markina, N.V. / Маркина Н.В. (2006). Художественный мир Рэя Брэдбери: традиции и новаторство: автореф. дис. ... канд. филол. наук. Самара: СГПУ. Maslova, V.A / Маслова В.A. (2008). Когнитивная лингвистика: [учебное пособие]. Минск: ТетраСистемс.

Morton, A. (2006). But are they right? The prospects for empirical conceptology. In Journal of cognition and culture, 6(1-2), p. 159-163.

Miller, L.V. / Миллер Л.В. (2000). Художественный концепт как смысловая и эстетическая категория In Мир русского слова, с. 39-45.

Murphy, G.L. (2002). The big book of concepts. Cambridge: MIT Press.

Nikonova, V.G / Ніконова В.Г. (2008). Конщептуальний простір трагічного в n'єсах Шекспіра: поетико-когнітивний аналіз: Дис. ... докт. філол. наук: Київ: Київський національний лінгвістичний університет.

Nikonova, V.G / Ніконова В.Г. (2008а). Трагедійна картина світу в поетиці Шекспіра. Дніпропетровськ: ДУЕП.

Ogneva, Е.А / Огнева Е.А. (2010). Когнитивно-коммуникативное пространство концептосферы художественного текста: результаты и перспективы 65 
моделирования. In B пространстве лингвистической мысли: сб. науч. $\mathrm{cm}$. Н.А. Беседина (отв. ред.). Белгород: Планета-Полиграф, с. 120-128.

Ogneva, E.A / Огнева Е.А. (2011). К вопросу о типологизации художественных концептов. In Современные иностранные языки: проблемы функиионирования и преподавания. Мозырь: УО МГПУ им. И.П. Шамякина, с. 120-125.

Ogneva, Е.А / Огнева Е.А. (2013). Когнитивное моделирование конщептосферы художественного текста. Москва: Эдитус.

Panasenko, N. (2013). Biblical motifs and allusions in short stories by Ray Bradbury. In International journal of humanities and social science, 3(11), p. 191-211.

Panasenko, N. (2012). Linguistic markers of emotional concept Love in literary texts. In US-China Foreign Language, 10 (4), p. 1067-1084.

Panasenko, N.I. / Панасенко Н.И. (2013a). Топофон в произведениях Рея Бредбери. In Наукові записки. Серія: Філологічні науки (мовознавство), 117. Кіровоград: РВВ КДПУ ім. В. Вінніченка, с. 115-119.

Popova, Z.D. \& Sternin, I.A. / Попова З.Д., Стернин И.А. (2007). Когнитивная лингвистика. Москва: АСТ, Восток-Запад.

Popova, Z.D. \& Sternin, I.A. / Попова 3.Д., Стернин И.А. (2010). Когнитивная лингвистика. Москва: АСТ, Восток-Запад.

Prikhodko, A.M. / Приходько А.М. (2008). Концепти $i$ конщептосистеми в когнітивно-дискурсивній парадигмі лінгвістики. Запоріжжя: Прем’єр.

Prokhorov, Yu.Е. / Прохоров Ю.Е. (2009). В поисках конщепта. 2-е изд. Москва: Флинта: Наука.

Radziievska, T.V. / Радзієвська Т.В. (2010). Нариси з концептуального аналізу та лінгвістики тексту. Текст - соиіум - культура - мовна особистість. Київ: Інформаційно-аналітичне агентство.

Ray Bradbury / Рэй Брэдбери. Available at: http://raybradbury.ru

Riftin, B.L / Рифтин Б.Л. (1991). Инь и Ян. Available at:

http://ec-dejavu.ru/i/In_Yan.html

Rudakova A.V. / Рудакова A.В. (2002). Когнитология и когнитивная лингвистика. Воронеж: Воронежский государственный университет. 
Selivanova, Е.А. / Селиванова Е.А. (2000). Когнитивная ономасиология. Киев: Фитоцентр.

Selivanova, O.O. / Селіванова О.О. (2008). Сучасна лінгвістика: напрями та проблеми: Підручник. Полтава: Довкілля-К.

Sibirtseva, Е.I / Сибирцева Е.И. (2014). Мир людей и мир машин в рассказах Рэя Брэдбери . In Вестник КРАУНЦ. Гуманитарные науки, 1(23), с. 62-65.

Significance of planet Venus in horoscope: Astrological point of view. Available at: http://www.futureforyou.co/significance-planet-venus-horoscope-astrological-pointview

Shevchenko, I.S. / Шевченко И.С. (2006). Подходы к анализу концепта в современной когнитивной лингвистике. In Вісник ХНУ. Харьків: ХНУ, 725, с. 192-195.

Shlionskaya, I. / Шлионская И. Романы "451 градус по Фаренгейту" и "И духов зла явилась рать". Available at: http://raybradbury.ru/articles/

Shurma, S.G. / Шурма С.Г. (2008). Поетика образу та символу в американському готичному оповіданні: лінгвокогнітивний аспект (на матеріалі новелістики Е. По, А. Бірса та Г. Лавкрафта): дис. ... канд. філол. наук. Київ: КНЛУ.

Slyshkin, G.G. / Слышкин Г.Г. (2004). Лингвокультурные конщепты и метаконцептыл. Автореф. дис. ... д-ра филол. наук. Волгоград: Волгоградский государственный педагогический университет.

Slyshkin, G.G. / Слышкин Г.Г. (2000). Лингвокультурные конщептьы прецедентных текстов. Москва: Academia.

Stepanov, Yu.S. / Степанов Ю.С. (1997). Константы. Словарь русской культурыл. Oпыт исследования. Москва: Языки русской культуры.

Stepanov, Yu.S. / Степанов Ю.С. (2007). Концеепты. Тонкая пленка ијивилизации. Москва: Языки славянских культур.

Tarasova, I.A. / Тарасова И.А. (2012). Поэтический идиостиль в когнитивном аспекте. Москва: Издательство "ФЛИНТА".

Tarasova, I.А. / Тарасова И.А. (2010). Художественный концепт: диалог лингвистики и литературоведения. In Вестник Нижегородского университета 
им. Н.И. Лобачевского. Нижний Новгород: Нижегородский университет им. Н.И. Лобачевского, 4 (2), с. 742-745.

Tresidder, J. / Тресиддер Д. (1999). Словарь символов. Available at: http://www.gumer.info/bibliotek_Buks/Culture/JekTresidder/

Tsmuh, О. / Цьмух О. (2011). Поняття "концепт" у сучасному лінгвістичному дискурсі. In Лінгвістичні студї, 22, с. 326-330. Available at: http://nbuv.gov.ua/UJRN/lingst_2011_22_67

Turner, M. (1996). The literary mind. Oxford: Oxford University Press.

Volkova, S.V. / Волкова С.В. (2015). Міфолорні образи в сучасних амеріндіанських прозових текстах. Херсон: Айлант.

Voloshina, O.V. / Волошина О.В. (2013). Концепти ПРАВДА, ІСТИНА в українськомовній, англійськомовній та грецькомовній картинах світу: Автореф. ... канд. філол наук. Донецьк: Донецький національний університет.

Vorobyova, O.P. / Воробьева О.П. (2013). Концептология в Украине: обзор проблематики. In Лингвоконцептология: перспективные направления: монография / под. ред. А.Э. Левицкого, С.И. Потапенко, И.В. Недайновой. Луганск: Изд-во ГУ "ЛНУ имени Тараса Шевченко", с. 10-37.

Wierzbicka, A. (1992). Semantics, culture, and cognition. Universal human concepts in culture-specific configurations. Oxford: Oxford University Press.

Wierzbicka, А. / Вежбицкая А. (1996). Язык. Культура. Познание. Москва: "Русские словари".

Vorkachev, S.G. / Воркачев С.Г. (2003). Концепт как "зонтиковый термин". In Язык, сознание, коммуникаџия. Москва: Гнозис, 24, с. 5-12.

Vorkachev, S.G. / Воркачев С.Г. (2004). Счастье как лингвокультурный конщепт. Москва: ИТДГК "Гнозис".

Yeltsova, L.F. / Ельцова Л.Ф. (2000). Концепты пространства в медицинской терминологии: Автореф. дис. ... канд. филол. наук. Рязань: Рязанский государственный медуниверситет им. акад. И.П. Павлова.

Zhabotynskaya, S.A. / Жаботинская C.A. (2009). Концепт домен: матричная и сетевая модели. Культура народов Причерноморья, 168, (1), с. 254-259. 


\section{Notes:}

${ }^{1}$ More about the culture of North American Indians and these and other symbols see in Волкова 2015.

${ }^{2}$ CLD - Cambridge Learner's Dictionary, LDCE - Longman dictionary of contemporary English.

\begin{tabular}{|c|c|c|}
\hline $\begin{array}{l}\text { Contact data } \\
\text { Yuliya Davydyuk, CSc., } \\
\text { (Philology), } \\
\text { Assistant professor, } \\
\text { Department of Foreign } \\
\text { Languages, Kmelnytsky } \\
\text { National University, } \\
\text { Instytutska Street, } \\
\text { 11, Khmelnytsky, } \\
\text { Ukraine } \\
\text { e-mail: } \\
\text { canada82@,mail.ru }\end{array}$ & $1+x x^{2}+$ & $\begin{array}{l}\text { Fields of interest } \\
\text { Cognitive poetics, } \\
\text { cognitive linguistics, } \\
\text { text linguistics, } \\
\text { stylistics. }\end{array}$ \\
\hline $\begin{array}{l}\text { Professor } \\
\text { Nataliya Panasenko, } \\
\text { DrSc. (Philology), } \\
\text { Chair of Language } \\
\text { Communication, } \\
\text { University of SS Cyril } \\
\text { and Methodius in } \\
\text { Trnava, Nám. Herdu, } 2 \\
\text { Slovakia } \\
\text { e-mail: } \\
\text { cindy777@mail.ru }\end{array}$ & 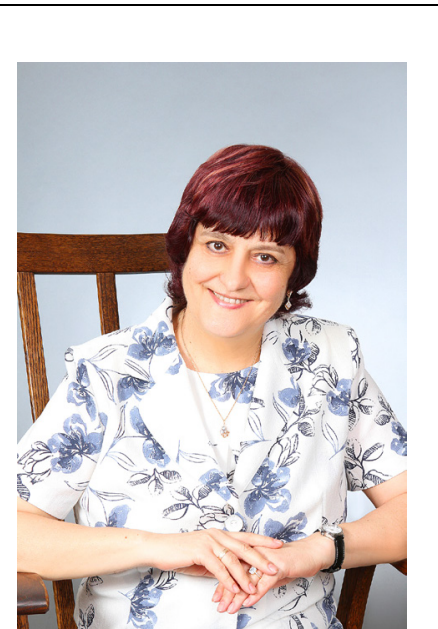 & $\begin{array}{l}\text { Stylistics, lexicology, } \\
\text { cognitive linguistics, } \\
\text { text linguistics, literary } \\
\text { time, psycholinguistics, } \\
\text { folklore (fairy tales, } \\
\text { songs) }\end{array}$ \\
\hline
\end{tabular}




\section{Résumé in English}

Our article highlights the results of the investigation of the literary FIRE and WATER concepts and their basic characteristics from a cognitive point of view. The case study is the embodiment and integrated analyses of these concepts in Bradbury's (science) fiction. We also undertake a brief review of theoretical material in the field of the concept studies, as well as their characteristics, structure, typology, functional properties and main definitions in the aspect of their symbolism. The research of the literary FIRE and WATER concepts was carried out in three steps - revealing their notional, image- and sense-bearing components. The description of a notional component is carried out by determining the semantic structure of the main lexemes for concepts designation and is based on the component and definitional analysis of dictionary interpretation of these lexemes. We have used the technique of the conceptual analysis in terms of conceptual metaphors for the research of an imagebearing component. The sense-bearing component is formed by the system of semantic attributes, which are determined on the basis of the component analysis of dictionary definitions of lexemes that are used for the concept correlates designation as a part of conceptual metaphorical schemes. Our research shows that the most common images used by Bradbury in his fiction are human beings, personified objects of inanimate nature and abstract notions. Such a personification is the part of the GREAT CHAIN OF BEING structure. The results show that the FIRE concept is mostly personified into the image of A MAN, while the WATER concept is mostly personified into the image of A WOMAN. This investigation proved our hypothesis that Bradbury implicitly uses Chinese philosophy of life (Yin and Yang) in his works as a base for personification. We have also carried out the psycholinguistic analysis of the texts under analysis based on Belyanyn's literary text typology, which has demonstrated the predominance of dark and complex types of the texts in Bradbury's (science) fiction.

Keywords: the male, the female, literary concepts, Ray Bradbury, symbol, the FIRE concept, the WATER concept, concept-element, conceptual metaphor, embodiment, image, text type. 


\section{Résumé in German}

Unser Artikel befasst sich mit Ergebnissen der Untersuchung der Literaturkonzepte FEUER und WASSER sowie ihrer wesentlichen Charakteristika aus kognitiver Perspektive. Gegenstand der Untersuchung ist die Verbalisierung dieser Konzepte in den Literaturwerken von Ray Bradbury. Der Artikel enthält den theoretischen Hintergrund unserer Forschung in Bezug auf die untersuchten Konzepte, ihre Charakteristika, Struktur, Typologie, funktionelle Eigenschaften und symbolische Bedeutungen. Die Untersuchung der Literaturkonzepte "Wasser" und "Feuer" wird in drei Schritten durchgeführt, wobei ihre begrifflichen, bildlichen und semantischen Komponenten festgestellt werden. Die Beschreibung der begrifflichen Komponente erfolgt durch die Feststellung der semantischen Struktur der Lexeme, die für die Bezeichnung der Konzepte wichtig sind, und beruht auf der begrifflichen und definitionalen Analyse der Wörterbuchbeschreibung dieser Lexeme. Für die Untersuchung der bildlichen Komponente wird die Methode der konzeptuellen Metapheranalyse eingesetzt. Die begriffliche Komponente wird durch das System begrifflicher Attribute gestaltet, die auf Grund einer Analyse der Wörterbuchbeschreibungen der für die Bezeichnung der konzeptuellen Korellate gebrauchten Lexeme in der Struktur konzeptueller Metapherschemata identifiziert werden. Unsere Untersuchung zeigt, dass die häufigsten in den Werken von Ray Bradbury verbalisierten sprachlichen Bilder folgendermaßen aussehen: Menschen, personifizierte Objekte der unbelebten Natur, und abstrakte Begriffe. Eine solche Personifizierung ist ein Bestandteil der konzeptuellen Struktur "die Große Kette des Seins". Die Ergebnisse zeigen, dass das Konzept FEUER vorwiegend durch das Image eines Mannes personifiziert wird, und das Konzept WASSER durch das Image einer Frau. Das bestätigt unsere Hypothese, dass Ray Bradbury implizite Elemente der chinesischen Philosophie (Yin und Yang) als Grundlage für die Personifizierung benutzt. Im Rahmen der Untersuchung der Literaturkonzepte WASSER und FEUER wurde auch eine psycholinguistische Analyse der Literaturwerke von Ray Bradbury durchgeführt, wobei Belyanyns Methode der Texttypologie benutzt wurde. Diese 
Analyse zeigte, dass in Bradburys Werken dunkle und komplizierte Texttypen vorherrschen.

Stichwörter: männlich, weiblich, Literaturkonzepte, Ray Bradbury, Symbol, Konzept FEUER, Konzept WASSER, konzeptuelle Metapher, Verbalisierung, Image, Texttyp.

\section{Résumé in French}

Dans notre article nous couvrons les résultats des études des concepts d'art FEU et EAU et de leurs caractéristiques principales du point de vue cognitif. Nous avons étudié la verbalisation de ces concepts dans les oeuvres littéraires de Ray Bradbury. Dans cet article nous faisons le tour du matériel théorique dans le domaine de l'étude des concepts, de leurs caractéristiques, structure, typologie, qualités fonctionnelles et des significations essentielles dans l'aspect de leur symbolique. L'étude des concepts d'art FEU et EAU a eu trois étapes: la révélation de leur composant conceptuel, figuratif et sémantique. La description du composant conceptuel se fait par la voie de l'établissement de la structure sémantique des lexèmes principaux pour la désignation des concepts et se base sur l'analyse sémique et celui de définition des interprétations de dictionnaire de ces lexèmes. Pour étudier le composant figuratif nous avons mis en jeu la méthode de l'analyse conceptuelle dans les termes conceptuels des métaphores. Le composant sémantique est formé par le système des attributs sémantiques qui se distinguent sur la base de l'analyse sémique des définitions de dictionnaire des lexèmes qui sont utilisés pour la désignation des concept-corrélats dans la combinaison des schémas conceptuels métaphoriques. Notre étude a montré que les images les plus répandues qui ont été verbalisées dans les œuvres de Ray Bradbury ce sont des êtres humains, des objets personnifiés de la nature et des notions abstraites. Telle personnification fait partie de la structure conceptuelle GRANDE CHAÎNE DE L'EXISTENCE. Les résultats obtenus ont montré que le concept FEU dans la plupart des cas se personnifie en image de l'homme et le concept EAU en image de la femme. Donc, nous avons eu la possibilité de prouver notre hypothèse sur l'utilisation implicite par Ray Bradbury des éléments de la philosophie chinoise YIN et YANG comme la 
raison de la personnification. Pendant notre étude des concepts d'art FEU et EAU nous avons fait l'analyse psycholinguistique des textes basée sur la méthode de Bélanin qui a montré la prédominance des types sombres et compliqués des textes dans œuvres littéraires de Ray Bradbury.

Mots-clés: masculin, féminin, concepts d'art, Ray Bradbury, symbole, concept FEU, concept EAU, concept-élément, métaphore conceptuelle, verbalisation, image, type du texte.

\section{Résumé in Russian:}

В нашей статье освещаются результаты исследования художественных концептов ОГОНЬ и ВОДА и их основных характеристик с когнитивной точки зрения. Исследованию подвергалась вербализация этих концептов в художественных произведениях Рэя Брэдбери. В работе был проведен краткий обзор теоретического материала в области изучения концептов, методологии анализа и основных значений в аспекте их символики. Методология исследования художественных концептов ОГОНЬ и ВОДА была проведена в три этапа - выявление понятийного, образного и смыслового компонента концепта. Описание понятийного компонента осуществляется путем установления семантической структуры основных лексем для обозначения концептов и основывается на компонентном и дефиниционном анализе словарных толкований этих лексем. Для исследования образного компонента задействована методика концептуального анализа в терминах концептуальных метафор. Смысловой компонент формируется системой смысловых атрибутов, которые выделяются на основе компонентного анализа словарных дефиниций лексем, которые используются для обозначения концепт-коррелятов в составе концептуальных метафорических схем. Данная методология была осуществлена в её непосредственной связи с китайской философией Инь и Ян: основные концепт-элементы, ОГОНЬ и ВОДА, были изучены с мужской и женской точек зрения. Наше исследование показало, что наиболее распространенные образы, 
вербализованные в произведениях Рэя Брэдбери, это человеческие существа, персонифицированные объекты неживой природы и абстрактные понятия. Такая персонификация является частью концептуальной структуры ВЕЛИКАЯ ЦЕПЬ БЫТИЯ. Результаты показали, что концепт ОГОНЬ главным образом персонифицируется в образ мужчины, а концепт ВОДА - в образ женщины. Это дало возможность доказать нашу гипотезу о прямом использовании Рэйем Брэдбери элементов китайской философии. В рамках исследования художественных концептов ОГОНЬ и ВОДА нами был также осуществлён психолингвистический анализ художественных произведений, основанный на методике Белянина, который продемонстрировал преобладание темных и сложных типов текстов в творчестве Рэя Бредбэри.

Ключевые слова: художественные концепты, индивидуальный стиль Рэя Брэдбери, символ, концепт ОГОНЬ, концепт ВОДА, концепт-элемент, методология, концептуальная структура, вербализация, образ, тип текста.

Article was received by the editorial board 3.06.16;

Reviewed 23.06.16 and 26.07.16.

Similarity Index 17\%. 